\title{
Değer Eğitimde Özdeşim Kurma: Hz. Muhammed (sav) Örneğiं*
}

\section{Identification in Values Education: The Case of the Prophet Muhammad (pbuh)*}

Sevgi COŞKUN KESKİN, Sorumlu Yazar. Doç. Dr.

Sakarya Üniversitesi, Eğitim Fakültesi, Türkçe ve Sosyal Bilimler Eğitimi Bölümü.

E-mail: scoskun@sakarya.edu.tr

ORGID: 0000-0001-2345-6789

İklima Betül ERTÜRK, Yüksek Lisans Öğrencisi.

Sakarya Üniversitesi, Eğitim Bilimleri Enstitüsü, Değerler Eğitimi.

E-mail: iklimabetulerturk@gmail.com

ORCID: 0000-0001-7631-9016

Zehra Betül KOCAMAZ, Yüksek Lisans Öğrencisi. Sakarya Üniversitesi, Eğitim Bilimleri Enstitüsü, Değerler Eğitimi.

E-mail: zbkocamaz44@gmail.com.

ORGID: 0000-0002-2148-8960

ISSN: 1303-880X e-ISSN: 2667-7504 http://ded.dem.org.tr

Geliş/Received: 25.12 .2018 Kabul/Accepted: 08.04 .2019 Makale türü/Article type: Araştırma/Research
Atıf/Citation: Coşkun Keskin, S., Ertürk, İ.B., \& Kocamaz, Z.B. (2019). Değer eğitimde özdeşim kurma: Hz. Muhammed (sav) örneği. Değerler Eğitimi Dergisi, 17 (37), 175-218, DOI: $10.34234 /$ ded.502014

* Bu çalışma ilk iki yazar tarafindan 05-06 Nisan 2018 tarihinde yapılan "3. Uluslararas Değerler Eğitimi Kongresi”nde sözlü bildiri olarak sunulmuştur. 3. Yazar ile birlikte çalışma genişletilerek yeniden yapılandırılmıştır.

* This study was presented as an oral presentation by the first two authors at the "3rd International Values Education Congress" held on 05-06 April 2018. With the third author, the study was extended and restructured. 
Öz: 14-15 yaş grubu, kimlik gelişiminin önemli olduğu dönemlerden biridir. Bireyler bu dönemde kendini gösterebilmek için kitle iletişim araçlarının etkisiyle popüler olarak nitelendirilen kişiler ya da fikirlerle kendilerini özdeşleştirirler. Değerlerine sahip çıkabilen bir nesil yetişmesi ve kimlik gelişiminin doğru bir şekilde tamamlanabilmesi için onlara özdeşleşebilecekleri, rol model olacak güçlü karakterlerin anlatılması önem arz etmektedir. Bu bağlamdan hareketle araştırmada, ergenlik döneminin başında olan çocukların değerler açısından rol model olan şahsiyetlerin hayatlarını öğrenmeleri ve kendilerini bu şahsiyetlerle özdeşleştirmelerinin mümkün olup olmadığ $\mathrm{Hz}$. Muhammed (sav) örneği ile araştırılmıştır. Bu nedenle değer eğitiminde örnek bir kişilik olarak Hz. Muhammed'in (sav) karşıllaştığı problemler karşısında nasıl davranışlar sergilediğine ilişkin ortaokul 8. sınıf öğrencilerinin düzeyine uygun, 8 etkinlik geliştirilmiştir. Çalışma 3 hafta boyunca, 8. sınıfa geçen, 23 öğrenciyle yürütülmüştür. Nitel araştırma yöntemlerinden eylem araştırması deseniyle yürütülen çalışmada veriler; görüşme, doküman ve araştırmacının katılımcı gözlemleriyle elde edilmiştir. Elde edilen veriler içerik analizi ile incelenmiş̧ir. Araştırma sonucunda çocukların yaşadıkları sorunlar karşında sergiledikleri barışçıl olmayan çözümlerin, Hz. Muhammed'in (sav) şahsiyeti bağlamında değerlendirildiğinde barışçıl çözümlere dönüştüğü tespit edilmiştir. Ayrıca etkinliklerden sonra Hz. Muhammed (sav) için söylenen Allah'ın kulu, Müslümanlığı öğreten, Kuranı Kerim, peygamber gibi çağrışımlar; hoşgörü, cesaret, saygı, güvenilir olma, barışsever (uzlaşmac1) gibi pek çok değeri içeren söylemlere dönüşmüştür.

Anahtar Kelimeler: Değer eğitimi, Hz. Muhammed (sav), Kimlik gelişimi, Özdeşleşme, Ergenlik dönemi

$\&$

Abstract: In this study, it was investigated whether it is possible for children in early adolescence to look up to, to learn from, the lives of individuals who are role models in terms of values and whether they identify themselves with these personalities. So our research was based on the example of the Prophet Mohammad (pbuh). For this reason, 8 activities were developed in accordance with the 8th grade level students, these activities designed to show how The Prophet Muhammad as an epitome of value education behave in the face of the problems. The study was carried out with 23 students in 8th grade for 3 weeks. Qualitative research methods is applied with a form of action research. The data were obtained through interviews, documents and participant observations. The data were analyzed by content analysis. The study found that, the non-peace- 
ful solutions that the children exhibit previously in the face of the problems turned into peaceful solutions when it was evaluated in the context of Muhammad's personality. Also after these activities, connotations of concepts like; the servant of God, teaching Islam, the Holy Quran, and Prophet Muhammad was evolved into discourses such as tolerance, courage, respect, trustworthiness, and peace-loving.

Keywords: Values education, Prophet Muhammad, Identification development, Identify, Adolescence period

\section{Giriş}

Birey yaşadığı değişimler sonucu; kendini tanıma, kendisinde olup bitenleri anlamlandırma konusunda sıkıntılar çeker. 'Ben kimim?' sorusu ile hayattaki yerini, amacını ve hedeflerini belirleme isteğiyle kimlik arayışı içerisine giren ergen, bu arayış esnasında yaşadığı sıkıntılara kendince çözümler üretir (Hökelekli,2013). Gençlik döneminin başlangıcı olarak bilinen 14-15 yaş grubu kimlik gelişiminin önemli olduğu dönemlerden biridir. Bu dönemde olumlu bir kişilik gelişimi çok önemlidir ve bireyin oluşturduğu kimlik ileriki yaşamında rollerini de belirlemektedir. Kimliğin oluşturulmasında çevre, aile, sahip olunan yaşam standartları ve bireyin psikolojik durumu etkilidir.

Ergenlik döneminde bireyler kendini gösterebilmek ve varlığını ispatlayabilmek için kitle iletişim araçlarının etkisiyle popüler olarak nitelendirilen kişiler ya da fikirlerle kendilerini özdeşleştirerek, bir bakıma onları model alarak kimlik arayışlarını gerçekleştirirler. Bu dönemde ki özdeşleşme Köknel'e (1979) göre, bireyin ruhsal yapısı içinde yaşadığı değişimle beraber aileden başlayarak çevredeki kişilere, fikirlere doğru ilerleyen bilerek ya da bilmeyerek etkilendiği, kabullendiği düşünce, duygu ve davranışlardan oluşan bir süreçtir.

Özdeşleşmenin ilk şartını bireyin objeye olan duygusal bağı oluşturmaktadır. Ergenlik döneminde birey her ne kadar dış dünyaya açılsa da anne-baba bu dönemde en çok model alınan kişilerin başında gelir (Yavuzer, 1982). Çevresinde model aldığı kişilerin kusurlarını gördükçe bunlarla yetinmeyerek yapısını, aile ve okul telkinlerini, çevresinde kabul görülmüş davranışları da değerlendirerek kendine idol olarak benimsediği güçlü ve ünlü kişileri örnek alır. Kılavuz'a (2002) göre birey özdeşleşeceği kişide ideal bir üstünlük ve olgunluk aradığı için bir taraftan çevresinde başarılı bir yetişkini örnek alırken diğer taraftan tarihi karakterleri de kendine model edinir. 
Ergenlik döneminde bireyin kimlik arayışı uzun bir süreç alabilir. Özellikle günümüzde küreselleşmenin de etkisiyle bu süreç daha da zor bir hal almaktadır. Köylü’ye (2013) göre her ne kadar küreselleşme sürecinin başlangıcı çok eskilere dayansa da yirminci asrın yarısından itibaren etkisini her alanda hissettirmiş, özellikle ahlaki alandaki etkileri büyük ölçüde negatif yönde olmuştur. Geleneksel aile yapısının bozulması, sosyo-ekonomik adaletsizlik, bilginin doğru olup olmadığına bakılmaksızın ona kolay ulaşılması gibi etkenler ahlaki yapıyı negatif yönde etkilemiştir.

Var olan gündemin takibi gerekli olmakta birlikte, bu yaş grubunun edindikleri bilgileri mantık süzgecinden geçirerek doğru ve yanlışı ayırmasıyla ilgili olarak sıkıntıların yaşandığı, pek çok haberde görülmektedir (Örnek haber için bkz. URL-1, URL-2, URL-3). Bu yaşta oluşturulan kimliğin, bireyin yaşamını etkilediği de bilinmektedir. Var olan bu sıkıntıların çözümünde değer merkezli bir eğitimin önemi oldukça büyüktür. Değerlerine sahip çıkabilen bir nesil yetişmesi için onlara rol model olacak güçlü karakterlerin tanıtılması gerekmektedir. Bu durumda da en güzel örnek hiç şüphesiz İslam'ın tüm öğretilerine eksiksiz uyan Hz. Muhammed (sav)'dir.

Hz. Muhammed (sav), ilk vahiyle muhatap olmadan önce de Mekke halk1 içinde değer verilen; güvenilirliği (Muhammed'ül $\operatorname{Emin}^{1}$ ), adaleti (Kâbe Hakemliği ${ }^{2}$ ), merhameti (Hılful Fudul/Erdemliler Cemiyeti ${ }^{3}$ ) ile örnek olan bir kişilikti. 610 y1lında kendisine ilk vahiy gelmiş, İslam dinini tebliğ görevi verilmiştir. Bu tebliğ sürecinde sergilediği örnek davranışlarla İslam dininin yayılmasını sağlamıştır. Cömertliğiyle, sabrıyla, çalışkanlığıyla, danışarak iş yapmasıyla insanları derinden etkilemeyi başarmış ve kendinden yıllar sonraki nesillere örnek olmaya devam etmiştir (Çakan ve Solmaz, 2014). Bu nedenlerle Hz. Muhammed (sav) gençlerin özdeşim kurmaları gereken örnek bir karakter

\footnotetext{
1 Muhammed'ül Emin: Toplum yaşamının yapı taşlarından olan güvenilir olma değeri aynı zamanda tüm Peygamberlerinde en önemli niteliklerindendir. Hz. Muhammed (sav) gençlik yıllarından itibaren Mekke'de "el-Emin" olarak adlandırılmıştır. "el-Emin" güvenilir olan demektir. (bkz. Sarıçam, Hz. Muhammed ve Evrensel Mesaj1, 2011, s.272)

2 Kâbe hakemliği: Hz. Muhammed (sav) Peygamber olmadan önce 35 yaşında, yenilenen Kâbe duvarına Hacerülesved'in yerleştirilmesi sırasında Kureyşlilere hakemlik yaptı. Taşı yerleştirme konusunda anlaşmazlık yaşayan Kureyş kabileleri mabedin kapısından ilk giren kişinin hakem olması yönünde uzlaşmaya vardılar. Kapıdan ilk giren kişi güvenilir ve adil olduğunu bildikleri $\mathrm{Hz}$. Muhammed (sav)'di. Bir bez parçası isteyen Hz. Muhammed (sav), o bezin üzerine Hacerülesved'i kendi elleriyle yerleştirmiştir. Kureyş kabilelerinin liderlerine bezin uçlarından tutmalarını söyleyip taşın konulacağı yere kadar beraber getirmelerini sağlamış ve taşı yerine koymuştur. Böylece yıllarca sürecek bir anlaşmazlık Peygamberimizin adaletli tutumuyla çözülmüş̧ür. (bkz. İbn Hişam, esSiret'ün-Nebeviyye, 1971, s.118)

3 Hılfü'l-Fudul: Bazı Kureyş kabilelerinin haksızlığa uğrayan kişilerin haklarını savunmak üzere oluşturdukları anlaşma neticesinde kurulmuş cemiyettir. $\mathrm{Bu}$ anlaşmanın gerçekleşmesine $\mathrm{Hz}$. Muhammed'in (sav) amcası Zübeyr öncülük etmiştir. Anlaşmaya genç yaşında Hz. Muhammed (sav) de katılmıştır. (bkz. Sarıçam, Hz. Muhammed ve Evrensel Mesajı, 2011, s.68)
} 
olduğu düşünülmektedir. Çünkü O döneminde yaşadığı problemlere hakkaniyet açısından bakabilen güçlü bir karakterdir ve pek çok değeri yaşayarak sergiles miştir. O'nun; "Allah beni zorlaştırıcı ve başkalarının hata yapmalarını isteyici değil; bir muallim ve kolaylaştırıcı olarak gönderdi." hadis-i şerifinde de dile getirdiği gibi, Hz. Muhammed (sav), insanlık eğitiminde önemli bir konuma sahiptir (Müslim, 1993).

2010 tarihli İlköğretim Din Kültürü ve Ahlak Bilgisi dersi öğretim programlał rında yer alan "Hz. Muhammed” öğrenme alanı kapsamında Hz. Muhammed'in (sav) beşeri özellikleriyle insanlara örnek olmasına yönelik 4. Sınıftan 8. Sınıfa kadar her sınıf düzeyinde bir ünite ayrılarak detaylı şekilde yer verilmiştir. Genel anlamda öğrencilerin bu öğrenme alanıyla Hz. Muhammed'in (sav) hayatı ve örnek davranışlarına yönelik bilgi edinmeleri ve erdemli davranışlarını örnek almaları amaçlanmıştır (MEB, 2017).

Yukarıda bahsedilen gerekçelerden hareketle bu çalışmada güven, sabır, çalışæ kanlık, sorumluluk, cesaret, adalet, merhamet, hoşgörü, affedicilik, sevgi, saygı gibi değerler açısından en güzel şekilde rol model olan Hz. Muhammed'in (sav) “Örnek Davranışları” konusu ile gençlerimize hayatlarında karşılaştıkları durumlara değerler penceresinden bakabilmeleri için farkındalık ve bilinç oluşturmak amaçlanmaktadır. Alan yazın tarandığında ergenlikte özdeşleşme ve rol model olma gibi çalışmalara teorik düzeyde (Eskiler ve Altunışık, 2017; Erdoğan ve diğerleri, 2015; Hökelekli, 2013; K1lavuz, 2002) yer verilmekle birlikte uygulamaya yönelik çalışmalara rastlanmamıştır. Bu nedenle çalışmada alana yönelik uygulama örneği sunmak ve sonuçlarını ortaya koyarak öneriler getirmek için; "Günlük yaşamda karşılaşılan problemlerle ilgili, Hz. Muhammed (sav)ile özdeşim kurarak nasıl çözümler sergilenir ve bu bağlamda hangi etkinlikler yapılabilir?" probleminden hareketle aşağıdaki alt problemlere cevap aranmaya çalışılmıştır. Bu genel problem doğrultusunda araştırmanın alt problemleri şunlardır;

1- "8. Sinıf İlköğretim öğrencilerinin Hz. Muhammed (sav) hakkındaki alglları nelerdir?"

2- "8. Sinıf İlköğretim öğrencileriyle yapılan etkinlikler, öğrencilerin Hz. Muhammed (sav) hakkındaki görüşlerini nasıl etkilemektedir ve öğrenciler O’nun hangi özellikleriyle özdeşim kurmaktadır?"

3- "8. Sinıf İlköğretim öğrencileri toplumsal sorunları çözme bağlamında Hz. Muhammed'i (sav) nasil örnek almaktadır?" 


\section{Yöntem}

\section{Araştırma Modeli}

Çalışmada, değer eğitiminde örnek bir kişilik olarak Hz. Muhammed'in (sav) "Örnek Davranışları" konusu ile gençlere hayatlarında karşılaştıkları durumlara değerler penceresinden bakabilmeleri için farkındalık ve bilinç oluşturmak amaçlanmaktadır. Amaca uygun olarak derinlemesine inceleme ve analiz yapabilmek için nitel araştırma yöntemlerinden eylem araştırması deseni kullanılmıştır. Mertler'e (2012) göre eylem araştırması, araştırmacının tespit ettiği uygulamada karşılaşılan sorunun derinlemesine incelendiği, var olan sorunun değiştirilebilmesi için gerekli önerilerin sunulduğu, ortaya konulan uygulamalarla araştırmacının değişimi gerçekleştirdiği ve elde ettiği sonuçlara göre iyileştirmeyi artırmak için yeni çözüm önerileri sunduğu araştırma şeklidir (Akt. Güler, Halıcıŏglu ve Taşğın, 2015).

Eylem araştırması uygulamayı yapan araştırmacının ve katılımcı grubun araştırma sürecine doğrudan katılımını sağladığı için yaparak yaşayarak öğrenmeyi ve böylece öğrenilenleri uygulamaya geçirmeyi desteklemektedir (Aksoy, 2003). Yapılan çalışmada araştırmacı öğretmenin etkinlikleri uygulamak, çalışmayı yönetmek, var olan problemlere çözüm aramak ve gözlem yapabilmek için uygulamada aktif şekilde rol alması gerekmiştir. Bu nedenle çalışma da eylem araştırması yöntemi kullanılmıştır.

\section{Çalışma Grubu}

Araştırmacı öğretmen ve katılımcıların aktif rol aldığı çalışma 2017-2018 eğitim-öğretim yllında Sakarya ilinin Hendek ilçesinde sosyo-ekonomik olarak orta düzeyli bir okulun ortaokul kademesinde 8. Sınıfa geçen 13-14 yaş grubuna dâhil 10 kız, 13 erkekten oluşan 23 katılımcı öğrenci ile gerçekleşmiştir. Çalışmada amaçlı örnekleme yöntemlerinden kolay ulaşılabilir örnekleme seçilmiştir. Araştırmacılardan birinin çalışma yapılan sınıfın öğretmeni olması, verilere ve öğrencilere kolay ulaşabildiği için (Yıldırım ve Şimşek, 2011) bu yöntem seçilmiştir. Okul ortamında yürütülen çalışma için velilerden sözlü izin alınmıştır. 


\section{Veri Toplama Süreci ve Araçları}

Araştırmanın probleminin çözümüne dair 8 ayrı etkinlik geliştirilmiştir. Araştırmanın veri toplama süreci tablo 1 de gösterilmiştir.

\begin{tabular}{lllll}
\hline \multicolumn{2}{l}{ Tablo 1: Veri Toplama Süreci } & & \\
\hline No & Uygulamanın Adı & Amacı & $\begin{array}{l}\text { Uygulanma } \\
\text { Tarihi }\end{array}$ & Süre \\
\hline 1 & $\begin{array}{l}\text { Kelime } \\
\text { ilişkilendirme }\end{array}$ & $\begin{array}{l}\text { Öğrencilerin etkinlik öncesi Hz. Muhammed (sav) } \\
\text { algılarını tespit etme }\end{array}$ & $12 / 12 / 2017$ & $10 \mathrm{dk}$ \\
\hline $\mathbf{2}$ & $\begin{array}{l}\text { Gösteri yöntemi ile } \\
\text { problem analizi }\end{array}$ & $\begin{array}{l}\text { Öğrencilerin çevrelerinde yaşanan olayların farkına } \\
\text { varmalarını sağlama-etkinliklere güdüleme }\end{array}$ & $12 / 12 / 2017$ & $15 \mathrm{dk}$ \\
\hline $\mathbf{3}$ & $\begin{array}{l}\text { Sorun ağacı } \\
\text { etkinliği }\end{array}$ & $\begin{array}{l}\text { Öğrencilerin bir problemi derinlemesine analiz } \\
\text { etme ve probleme yönelik çözüm önerisi üretme } \\
\text { becerilerini geliştirme }\end{array}$ & $12 / 12 / 2017$ & $\begin{array}{l}25+40 \\
\mathrm{dk}\end{array}$ \\
\hline $\mathbf{4}$ & $\begin{array}{l}\text { Örnek olay } \\
\text { incelemesi }\end{array}$ & $\begin{array}{l}\text { Öğrencilerin olaylara değerler penceresinden } \\
\text { bakabilmesini ve değer sınıflaması yapabilmesini } \\
\text { sağlama }\end{array}$ & $19 / 12 / 2017$ & $40 \mathrm{dk}$ \\
\hline $\mathbf{5}$ & Poster etkinliği & $\begin{array}{l}\text { Öğrencilerin etkili iletişim-sunuş ve grup çalışması } \\
\text { becerisini artırma /değer sınıflaması yapabilmesini } \\
\text { sağlama }\end{array}$ & $19 / 12 / 2017$ & $40 \mathrm{dk}$ \\
\hline $\mathbf{6}$ & Empati etkinliği & $\begin{array}{l}\text { Problemlere Hz. Muhammed'in (sav) bakış } \\
\text { açısıla bakmalarını sağlama/ Hz. Muhammed } \\
\text { (sav) ile özleşebilecekleri noktaları keşfetme }\end{array}$ & $26 / 12 / 2017$ & $15 \mathrm{dk}$ \\
\hline $\mathbf{7}$ & Ayet yorumlama & $\begin{array}{l}\text { Etkinlikler kapsamında fark ettikleri noktalarla } \\
\text { ayeti inceleyerek yaşlarına uygun ilke ve mesajlar } \\
\text { çıkarmalarını sağlama }\end{array}$ & $26 / 12 / 2017$ & $15 \mathrm{dk}$ \\
\hline $\mathbf{8}$ & Kavram haritası & $\begin{array}{l}\text { Süreç etkinlikleriyle öğrencilerin Hz. Muhammed } \\
\text { (sav) hakkındaki algılarının ne durumda olduğunun } \\
\text { tespiti }\end{array}$ & 09/01/2018 & $15 \mathrm{dk}$ \\
\hline
\end{tabular}

Çalışmada ilk olarak öğrencilerin süreç öncesi kelime ilişkilendirme testi ile Hz. Muhammed (sav) algıları tespit edilmiştir. Ardından 3 hafta boyunca süreç etkinlikleri uygulanmış ve çalışma tamamlandıktan 2 hafta sonra öğrencilerin algılarının ne olduğunun tespiti amacıyla süreç sonrası kavram haritası oluşturmaları sağlanmıştır. Bu süreçte; gösteri yöntemi ile problem analizi, sorun ağacı etkinliği, örnek olay incelemesi, poster etkinliği, empati etkinliği ve ayet yorumlama etkinlikleri uygulanmıştır. Araştırma toplamda beş haftada tamamlanmıştır. Çalışmada veriler, araştırmacılardan birinin katılımcı gözlemi ve dokümanlar ile elde edilmiştir.

\section{Katılımcı gözlem}

Öğrencilerin söylemleri çalışma boyunca kamera ile kayıt altına alınmıştır. Toplamda 60 dakikalık video kaydı oluşmuştur. Eylem araştırmasında katılımcı araştırmacının rolü, çalışma sürecinde etkinlikleri uygulama, çalışmayı yönetme, var olan problemlere çözüm arama ve gözlem yapabilme şeklindedir. 


\section{Doküman analizi}

Etkinlikler sırasında ortaya çıkan ürünler doküman olarak toplanmıştır. Tablo 1 deki etkinliklerden elde edilen veriler doküman analizine tabi tutulmuştur. Araştırma kapsamında uygulanan etkinlikler kısaca aşağıda açıklanmıştır:

Kelime ilişkilendirme etkinliği. Çalışmada süreç öncesi uygulanan ilk etkinliktir. Kelime ilişkilendirme testi ile öğrencilerin Hz. Muhammed (sav) ile ilgili var olan algıları tespit edilmeye çalışılmıştır. Uygulamaya başlamadan öğrencilere kelime ilişkilendirme formu dağıtılmış ve Hz. Muhammed (sav) denilince akıllarına gelen ilk beş kelimeyi yazmaları, bir tanesini seçerek, neden onu seçtiklerini açıklamaları istenmiştir.

Gösteri yöntemi ile problem analizi. Öğrencileri derse güdülemek ve çevrelerinde yaşanan olayların farkına varmalarını sağlamak amacıyla "çocuğa arabayla çarptıktan sonra hastaneye götüreceğim deyip bir üst sokağa bırakıp kaçan adam" konulu güncel bir problemi yansitan haber videosu izletilmiştir. Video bittikten sonra bu durumun onları nasıl etkilediği sorulmuş ardından "sizce bu problemin nedeni ne olabilir?” sorusu yöneltilmiştir.

Sorun ăgacı etkinliği. Gösteri yöntemiyle verilen problem gibi öğrencilerin çevrelerinde tanık oldukları ya da haberlerde gördükleri bu şekilde olaylar olup olmadığı sorulmuştur. Öğrencilerin dikkatini çeken haberler ve çevrelerinde gördüğü olumsuz durumlar; "kediye işkence çektirip sonra lağım kuyusuna atan adam, çocuğunu denize atıp polis çă̆ıran kadın, Hıristiyanların çocuğu suya sokup boğması, sarhoş adamın arabayla çocuğa çarpması, zevk için hayvan vuran adam, köpek yavrusunu çuvala koyup denize atan adam, 5 aylık çocuğa işkence edilmesi, adamın çocuğa çarptıktan sonra doktora götürüyorum deyip üst sokakta atması, Çin'de köpeği boğazından bağlayıp ateşe atan adam, barınaktaki köpeklerin kulaklarının kesilmesi, uyuyan köpeğe tekme atan kişi, sosyal medyada bir kişinin hayvanları öldürüp fotoğraflarını yayınlaması, başkasıyla ilişkisi olduğunu öğrenen engelli çocuğuna sıcak su döken kadın”, şeklinde tahtaya not edilmiştir. Öğrencilerden tahtaya not edilen sorunlardan bir tanesini seçip, problemin nedenleri ve probleme yönelik kendi çözüm önerilerini sorun ağacı etkinliği formuna yazmaları istenmiştir. Öğrenciler problemlerine yönelik çözüm önerilerini sunmuşlardır. Öğrenci sunumları bittikten sonra öğretmen tarafından problemlerin temelinde yatan etkenler özetlenmiş ve Hz. Muhammed (sav)' in gönderildiği toplumun durumu ve öğretileri hakkında k1saca bilgi verilmiştir. 
Örnek olay incelemesi. 3'erli gruba ayrılan öğrencilere Hz. Muhammed (sav)' in hayatında yaşadığ 1 örnek olaylardan hareketle değerlerin ve becerilerin olduğu; " $H z$. Muhammed (sav) çalışmayı sever ve zamanını iyi değerlendirirdi, Hz. Muhammed (sav) insanlara değer verirdi, Hz. Muhammed (sav) güvenilir bir insand1, Hz. Muhammed (sav) bilgiye önem verirdi, Hz. Muhammed (sav) hoşgörülü/merhametli ve affediciydi, Hz. Muhammed (sav) sabırlı ve cesaretliydi, Hz. Muhammed (sav) danışarak iş yapard, Hz. Muhammed (sav) hakkl gözetirdi, Hz. Muhammed (sav) doğayl ve hayvanlarl severdi" konulu birer başlık verilmiş ve bu başlıklar hakkında kısaca araştırma yapmaları istenmiştir. Konu başlıklarına ait örnek olaylar her gruba karışık olarak dağıtılımış ve kendi başlıklarına uygun olan örnek olayları sınıflandırmaları istenmiştir. Kendi başlığına uygun olmayanları ise diğer grup üyeleriyle değerlendirerek, hangi gruba ait olduğu düşünülüyorsa o gruba vermeleri istenmiştir.

Poster etkinliği. Gruplara birer adet yukarıda bahsedilen örnek olay incelemesi içinde yer alan konu başlıklarının bulunduğu fon kartonu verilmiş, daha önce sınıflandırdıkları Hz. Muhammed (sav)'in örnek davranışlarının yer aldığı örnek olay metinlerini ve konuyla alakalı resimleri, posterleri $(35 \times 50 \mathrm{~cm})$ üzerine yapıştırmaları istenmiştir. Tamamlanan çalışmalar tahtaya asılmış ve her grubun sözcüsü sırayla tahtaya gelerek örnek olaylarını niçin bu başlık altında aldıklarını anlatarak posterlerini sunmuşlardır. Grupların oluşturduğu posterler birbirinin devamı şeklinde $(310 \times 50 \mathrm{~cm})$ duvara yapıştırılmıştır. Daha sonra öğretmen tarafindan her öğrenciye bireysel olarak Hz. Muhammed (sav)'in örnek davranışlarını anlatan 69 ayet ve hadis eşit olarak dağıtılmış, oluşturdukları posterlerden ilgili yerlere yapıştırmaları istenmiştir. (Örnek için bkz. görsel 1, 2 ve 3)

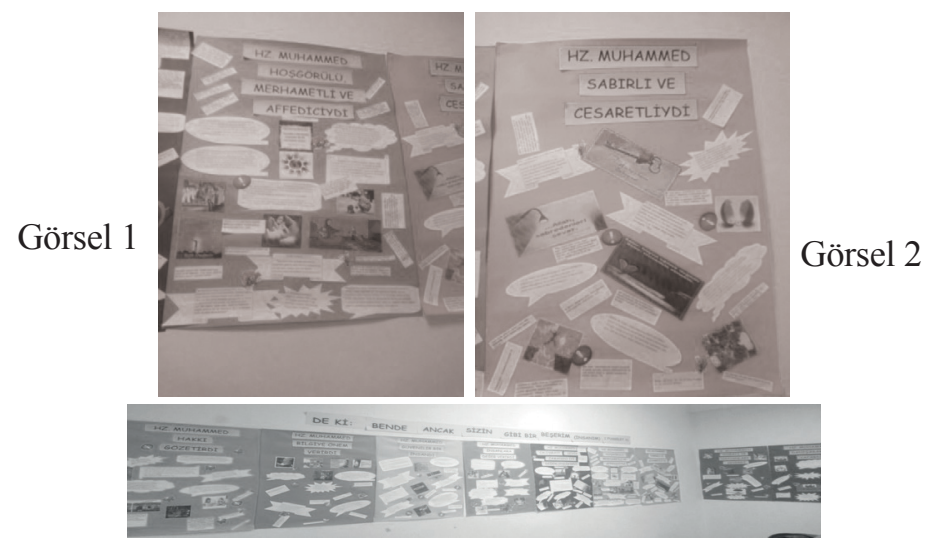

Görsel 3 
Empati etkinliği. Poster etkinliği tamamlandıktan sonra öğrencilere, sorun ağacı etkinliği esnasında seçtikleri 13 güncel problem (bkz. Sorun ağacı etkinliği) ve kendi çözüm önerileri hatırlatılarak ; "Peygamberimiz olsaydı bu problem karşısında nasıl bir çözüm yolu bulurdu? ” sorusu yöneltilmiş ve öğrencilerin düşünmesi istenmiştir. Buldukları fikirler yazılı olarak alınmıştır. Ardından etkinlikler sonrasında öğrencilerin kendi çözüm önerileri tekrar sorulmuş ve Hz. Muhammed'in (sav) örnek davranışlarını da göz önüne alarak cevaplamaları istenmiştir.

Ayet yorumlama. Öğrencilerden "De ki: Ben de ancak sizin gibi bir beşerim (insanım)" (Fussilet/6) ayeti kerimesini Hz. Muhammed (sav)'in bize örnek olarak gönderilmesi açısından değerlendirmesi ve ayetten yaşlarına uygun ilke ve mesajlar çıkarmaları istenmiştir.

Kavram haritası. Çalışmada süreç sonrası olarak uygulanan etkinliktir. Süreç içi etkinliklerden 2 hafta sonra öğrencilerin Hz. Muhammed (sav)' in sahip olduğu değerleri ve becerileri kavram haritasıyla bireysel olarak sunmaları sağlanmıştır.

Yapılan tüm etkinlikler neticesinde öğrencilerin karşılaştıkları problemleri Hz. Muhammed (sav)'in hayat felsefesi çerçevesinde değerlendirmesi, aynı zamanda yaşantısında sergilediği değer merkezli çözüm önerilerini kendi hayatlarına transfer etmeleri amaçlanmıştır. Etkinlikler sırasında öğrencilerin eleştirel düşünme, bilimsellik, Kur'an-1 Kerim mealini okuma, araştırma, empati, istişare, zaman yönetimi, etkili iletişim ve sunuş becerilerini sergilemeleri ve geliştirmeleri desteklenmiştir.

\section{Verilerin Analizi}

Çalışmada veriler içerik analizi ile incelenmiştir. İçerik analizi yorumlayıcı bakış açısıyla incelenen iletişim verilerinde, verilmek istenen mesajın ne olduğunu anlamaya yönelik tümevarımcı bir analiz biçimidir (Güler, Hacıŏlu ve Taşğın, 2015). Nitekim içerik analizinde amaç, toplanan verileri açıklayabilecek kavram ve ilişkilere ulaşmaktır (Yıldırım ve Şimşek, 2011). Çalışmada içerik analizi çerçevesinde verilerin analizi; veri işleme, verileri kodlama, tema oluşturma, ön bilgileri ve son bilgileri karşılaştırma, kendi çözüm öneriyle Hz. Muhammed (sav)'in çözüm önerilerini karşılaştırma ve geçerlilik güvenirliği sağlama olmak üzere beş aşamada gerçekleştirilmiştir:

\section{Veri işleme}

Her bir öğrenciye bir numara verilerek video kayıtları, söylemler ve yazılı dokümanlar bilgisayar ortamına aktarılmıştır. 


\section{Verileri kodlama}

Elde edilen veriler araştırmacılar tarafindan tartışılarak kodlar oluşturulmuştur. Örneğin; Ö19'un; "Peygamberimize o zamanlarda çok kötülük yaparlardl peygamberimiz sabırlı davranırdl." şeklindeki söylemi "sabırlı" olarak kodlanmıştır. Yine Ö1'in "Kendi fiziksel bakımina önem verirdi. Asla pis klyafet giymezdi, beyaz beyaz giyinirdi." şeklindeki söylemi "temizlik” olarak kodlanmıştır.

\section{Tema oluşturma}

Kodlardan ortak temalara ulaşılmıştır. Ön uygulama ve son uygulama kodlarından; (1) Hz. Muhammed'in (sav) sahip olduğu değerler, (2) Hz. Muhammed'in (sav) karakter özellikleri, (3) Hz. Muhammed (sav) ile ilişsilendirilen Islam'a ait şart ve semboller, (4) Hz. Muhammed'in (sav) fiziksel özellikleri, (5) Hz. Muhammed'in (sav) Allah ile olan ilişkisi ve (6) Hz. Muhammed (sav) ile ilişkilendirilen diğer kavramlar temalarına ulaşılmıştır. Örneğin: "sabırlı" kodu, Hz. Muhammed'in (sav) sahip olduğu değerler temasına alınırken, "temizlik" kodu ise Hz. Muhammed'in (sav) karakter özellikleri temasına dâhil edilmiştir.

Toplumsal sorunları çözme bağlamında kendisi ve Hz. Muhammed (sav) ile özdeşleştirdikleri çözüm önerilerinde ise; “(1) kendisinden daha makul bir şekilde yaklaşarak, (2) kendisiyle aynı şekilde davranarak, (3) kendisinden daha sert ceza vererek problemi çözeceğini ifade edenler" şeklinde 3 tema oluşturulmuştur.

Ön bilgilerle, son bilgileri/kendi çözüm önerileriyle, Hz. Muhammed'in (sav) çözüm önerilerini karşılaştırma. Kelime ilişkilendirme ve kavram haritası formları ile elde edilen kodlardan ulaşılan temalara ait veriler karşılaştırılarak tablolaştırılmıştır. Ayrıca sorun ağacı etkinliği sırasında süreç öncesi etkinliklerden önce öğrencilerin kendi çözümleri ile süreç sonrası Hz. Muhammed (sav) ile özdeşleştirdikleri çözüm önerileri de tablolarda karşılaştırılarak yer verilmiştir.

\section{Araştırmanın Geçerlilik ve Güvenirliği}

Araştırma da inandırıcılığı (iç geçerlilik) sağlamak için uzman görüşlerinden faydalanılmıştır. Öğrencilerin söylemleri üzerinden uzmanlar tarafından birlikte kodlar oluşturulmuştur. Uzmanların fikir ayrıllğına düştüğü noktalarda farklı bir uzmanın görüşü alınmıştır. Uzmanlar elde edilen kodları derinlemesine analiz etmiş, tartışarak elde ettikleri kodlardan temalara ulaşmış bu temalar da tablolaştırılmıştır. Ayrıca çalışmada öğrenci söylemlerine sık sık yer verilerek çalışmanın güvenilirliği sağlanmaya çalışılmıştır. 


\section{Bulgular}

Araştırmanın soruları bağlamında, 8. sınıf öğrencilerinin Hz. Muhammed (sav.) hakkındaki algıları ve etkinliklerin bu algıları nasıl etkilediği ve öğrencilerin toplumsal sorunları çözme sırasında Hz. Muhammed'i (sav) nasıl örnek aldıklarına dair bulgular aşağıda sunulmuştur.

Sekizinci Sınıf Öğrencilerinin Hz. Muhammed (sav) Hakkındaki Algıları ve Etkinliklerin Bu Algıları Nasıl Etkilediğine Dair Bulgular

Aşağıda öncelikle etkinliklerin öncesi ve sonrası öğrencilerin Hz. Muhammed (sav) hakkındaki bilgileri karşılaştırmasına ve ayrıca etkinlikler sonucunda $\mathrm{Hz}$. Muhammed'in (sav) beşer olma özelliğinin öğrenciler tarafından yorumlanmasina dair bulgulara yer verilmiştir.

\section{Öğrencilerin etkinlik öncesi ve sonrası Hz. Muhammed (sav) hakkındaki bilgilerini karşılaştırma}

Hz. Muhammed (sav) ile ilgili etkinlik öncesi ve sonrası öğrencilerin algıları analiz edildiğinde; "Hz. Muhammed'in (sav) sahip olduğu değerler, $\mathrm{Hz}$. Muhammed'in (sav) karakter özellikleri, Hz. Muhammed (sav) ile ilişkilendirilen Islam'a ait şart ve semboller, Hz. Muhammed'in (sav) fiziksel özellikleri, Hz. Muhammed'in (sav) Allah ile olan ilişkisi ve Hz. Muhammed (sav) ile ilişkilendirilen diğer kavramlar" temaları elde edilmiştir. Bu temalara etkinlik öncesi ve sonrası alg1 karşılaştıran tablolarda yer verilmiştir.

Hz. Muhammed'in (sav) sahip olduğu değerler teması. Tablo 2 de Hz. Muhammed'in (sav) etkinlik öncesi ve sonrası sahip olduğu değerler karşılaştırılarak verilmiştir.

\begin{tabular}{|c|c|c|c|c|c|c|c|}
\hline \multicolumn{4}{|c|}{ Ön uygulama } & \multicolumn{4}{|c|}{ Son uygulama } \\
\hline Algı & Özellik & Siklık & Toplam & Alg1 & Özellik & Siklık & Toplam \\
\hline \multirow{15}{*}{ 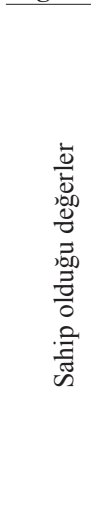 } & Sayg11 & 7 & \multirow{15}{*}{38} & \multirow{15}{*}{ 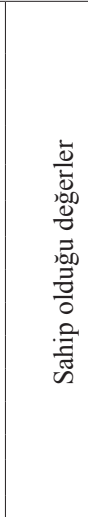 } & Güvenilir & 22 & \multirow{15}{*}{171} \\
\hline & Sevgi & 6 & & & Adaletli/hakkaniyetli & 21 & \\
\hline & Dürüst-doğru & 6 & & & Hoşgörülü & 20 & \\
\hline & Sabırlı & 4 & & & Sabirlı & 19 & \\
\hline & Adaletli & 3 & & & Cesaretli & 18 & \\
\hline & Yardımsever & 3 & & & Çalışkan & 17 & \\
\hline & Güvenilir & 2 & & & Merhametli & 16 & \\
\hline & Merhametli & 2 & & & Affedici & 13 & \\
\hline & Azimli & 2 & & & Saygili & 8 & \\
\hline & Affedici & 1 & & & Dürüstlük-doğruluk & 6 & \\
\hline & Cömert & 1 & & & Sevgi & 4 & \\
\hline & Sadakat & 1 & & & Yardımsever & 3 & \\
\hline & & & & & Azimli & 2 & \\
\hline & & & & & Cömert & 1 & \\
\hline & & & & & Bilimsellik & 1 & \\
\hline
\end{tabular}


Tablo 2 de görüldüğü üzere etkinlik öncesinde Hz. Muhammed'in (sav) sahip olduğu 11 değer (saygl, sevgi, dürüst-doğru, sabırll, adaletli, yardımsever, güvenilir, merhametli, azimli, affedici, cömert, sadakat) öğrenciler tarafindan vurgulanmıştır. Ancak yapılan etkinlikler sonrasında Hz. Muhammed'in (sav) sahip olduğu düşünülen 14 değere (güvenilir, adaletli/hakkaniyetli, hoşgörülü, sabırll, cesaretli, çalışkan, merhametli, affedici, saygıll, dürüstlük/doğruluk, sevgi, yardımsever, azimli, cömert, bilimsellik) sıklıklar artarak yer verilmiştir. Bu sıklık, ön uygulamanın neredeyse dört katından $(37 / 171=4,62)$ fazladır. Her iki uygulamada da "saygl, sevgi, dürüstlük-doğruluk, sabırl, adaletli, yardımsever, güvenilir, merhametli, azimli, affedici, cömert" değerleri vurgulanmıştır. Bunun yanı sıra her iki uygulamada; oransal olarak kıyaslandığında; "saygl (7/8), sevgi (6/4), dürüstlük/doğruluk (6/6), yardımsever (3/3), azimli (2/2), cömert (1/1)" değerlerine neredeyse eşit bir şekilde yer verilmiştir. Ancak sabırlı (4/19), adaletli/hakkaniyetli (3/21), güvenilir olma (2/22), merhametli (2/16), affedici (1/13) oranları, etkinlikler sonrasında oldukça artmıştır. Hz. Muhammed'in (sav) hoşgörülü olma (20), cesaretli olma (18), çalışkan olma (17) gibi sahip olduğu değerler ilk uygulamada ifade edilmezken, ikinci uygulamada dikkat çeken bir sıklıkla yüksek oranda ifade edilmiştir. Yine ilk uygulamada bilimsellik (1) değeri ifade edilmezken, etkinlikler sonrasında bu değer de ifade edilmiştir. Ayrıca "sadakat (1)" değerine birinci uygulamada yer verilirken, ikinci uygulamada yer verilmediği de görülmüştür. Aşağıda Hz. Muhammed'in (sav) sahip olduğu değerlere ilişkin öğrenci söylemlerine yer verilmiştir.

\begin{tabular}{|c|c|}
\hline Etkinlik Öncesi Söylem Örnekleri & Etkinlik Sonrası Söylem Örnekleri \\
\hline 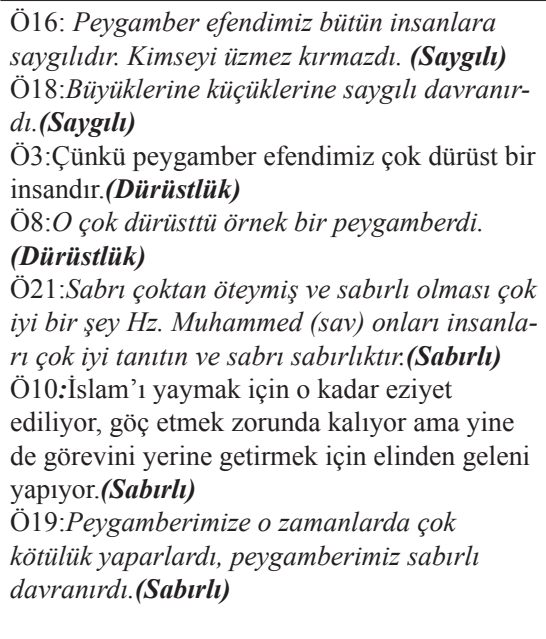 & 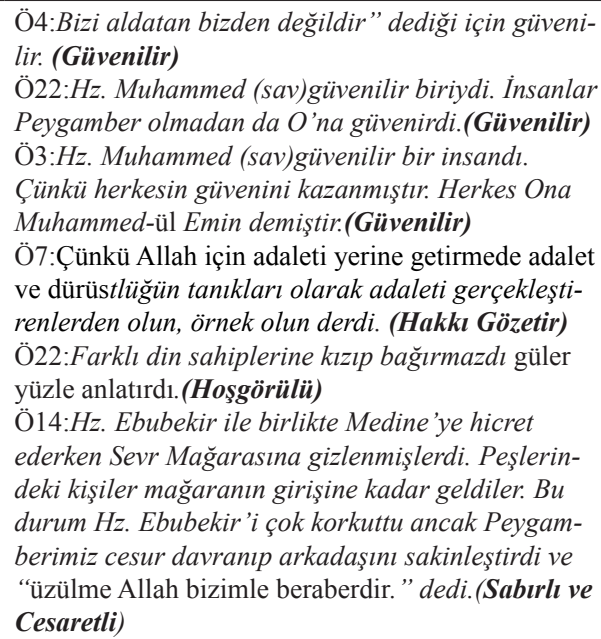 \\
\hline
\end{tabular}


Ö13:Hz. Muhammed (sav)köleyle aynı yemeği yer, aynı şeyi içer ve kendini kimseden üstün göremez.(Adaletli olma)

Ö5:Peygamber efendimiz amcasını öldüren

Vahşi adlı savaşçıyı bile affetmiş ama onu görmek istememiş. Çünkü onu görünce amcasını hatırliyormuş.(Affedici)
Ö14:İnsanlara merhamet etmeyene Allah da merhamet etmez. Hadisi vardır.(Merhametli)

Ö10:Torunlarını severdi çocuklara değer verip severdi.(Merhametli)

Ö21:Affediciydi ve insanlara kin tutmazdl.(Affedici)

Söylemler incelendiğinde öğrencilerin süreç öncesi Hz. Muhammed (sav)'in sahip olduğu değerleri doğru anlamlandırdıkları görülmektedir. Ancak Ö3, Ö8, Ö16, Ö18, Ö21 adlı öğrencilerin açıklamaları incelendiğinde belirttikleri değerlere ilişkin açıklama yapmakta zorlandıkları; Ö5, Ö10, Ö13, Ö19 adlı öğrencilerin söylemlerinden ise belirttikleri değerlere ilişkin Hz. Muhammed (sav)'in hayatından doğru örnekler vererek açıklamalarda bulunabildikleri görülmüştür. Son uygulama söylemleri incelendiğinde öğrencilerin değerleri doğru anlamlandırdıkları ve Hz. Muhammed'in (sav) hayatından doğru örneklerle ilişkilendirdikleri görülmüştür. Aynı zamanda öğrencilerin son uygulama söylemlerinde Hz. Muhammed'in (sav) karakter özelliklerine ve çalışma sırasında var olan hadislerine vurgu yaptıkları görülmüştür.

Hz. Muhammed'in (sav) sahip olduğu karakter özellikleri teması. Aşağıda Hz. Muhammed (sav)'in sahip olduğu karakter özelliklerine dair ön uygulama ve son uygulamada elde edilen veriler karşılaştırılarak tablo 3 de gösterilmiştir.

\begin{tabular}{|c|c|c|c|c|c|c|c|}
\hline \multicolumn{4}{|c|}{ Ön uygulama } & \multicolumn{4}{|c|}{ Son uygulama } \\
\hline Alg1 & Özellik & Sıklık & Toplam & Alg1 & Özellik & Sıklık & Toplam \\
\hline \multirow{13}{*}{ 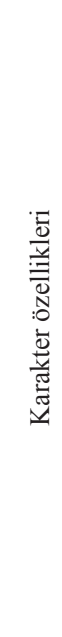 } & İyi insan & 7 & \multirow{13}{*}{22} & \multirow{13}{*}{ 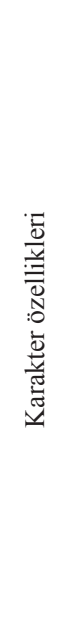 } & Bilgiye önem verirdi & 20 & \multirow{9}{*}{132} \\
\hline & Güzel sözlü & 4 & & & Hayvanları ve doğayı severdi & 18 & \\
\hline & İyi dost/arkadaş & 3 & & & Danışarak iş yapardı & 15 & \\
\hline & Temizlik & 2 & & & Zamanı iyi değerlendirirdi & 15 & \\
\hline & Güzel ahlaklı & 2 & & & İnsanlara değer verirdi & 14 & \\
\hline & Ağırbaşlı & 1 & & & İyilik meleği/iyi insan & 11 & \\
\hline & $\begin{array}{l}\text { Kötülüğümüzü } \\
\text { istemeyen }\end{array}$ & 1 & & & $\begin{array}{l}\text { Hiç kimsenin kalbini kır- } \\
\text { mazd }_{1}\end{array}$ & 8 & \\
\hline & Güler yüzlü & 1 & & & Kötü söz söylemez & 6 & \\
\hline & Güzel davranışlı & 1 & & & Dinine önem verirdi & 3 & \\
\hline & & & & & $\begin{array}{l}\text { Nerede nasıl davranacağını } \\
\text { bilirdi }\end{array}$ & 3 & \\
\hline & & & & & Örnek hareketleri var & 2 & \\
\hline & & & & & İyi arkadaş & 2 & \\
\hline & & & & & Normal insan & 2 & \\
\hline
\end{tabular}




\begin{tabular}{ll}
\hline Vicdanlı & 2 \\
Bizleri sever kollardı & 2 \\
Ön yargılı değil & 2 \\
Her şeye olumlu bakar & 2 \\
Ağırbaşlı & 1 \\
Problem çözen & 1 \\
İyinin yanında & 1 \\
Güzel ahlaklı & 1 \\
Görgülü & 1 \\
\hline
\end{tabular}

Tablo 3 incelendiğinde etkinlik öncesinde öğrenciler tarafından, Hz. Muhammed (sav)'in sahip olduğu 9 karakter özelliğine (iyi insan, güzel sözlü, en iyi dost/arkadaş, temizlik, güzel ahlakll, ağırbaşll, kötülü̈̆̈̈müzü istemeyen, güler yüzlü, güzel davranış sergileyen) vurgu yapılmıştır. Yapılan etkinlikler neticesinde Hz. Muhammed (sav)'in sahip olduğu düşünülen 22 karakter özelliğine (bilgiye önem verirdi, hayvanlarl ve doğayı severdi, danışarak iş yapard, zamanı iyi değerlendirirdi, insanlara değer verirdi, iyilik meleği/iyi insan, hiç kimsenin kalbini kırmazdl, kötü söz söylemez, dinine önem verirdi, nerede nasll davranacağını bilirdi, örnek hareketleri var, iyi arkadaş, normal insan, vicdanll, bizleri sever kollardl, ön yargllı değil, her şeye olumlu bakar, ağırbaşll, problem çözen, iyinin yanında, güzel ahlakl, görgülü) değinilmiştir. Uygulamalar sonucunda elde edilen ikinci verilerin vurgulanma sıklı̆ıının, ön uygulamaya göre altı kat $(22 / 132=6)$ arttığı görülmektedir. Her iki uygulamada da değinilen karakter özellikleri; "iyi insan, iyi arkadaş/dost, güzel ahlakll, ağırbaşll" olmasıdır. Bunun yanı sıra her iki uygulamada da ifade edilen; "iyi arkadaş/ dost (3/2), güzel ahlaklı (2/1), ağırbaşlı (1/1) 'karakter özellikleri oransal olarak değerlendirildiğinde neredeyse eşit bir dağılım gösterdikleri tespit edilmiştir. Ancak ön uygulamada belirtilen karakter özelliklerinden "güzel sözler (4), temizlik (2), kötülüğümüzü istemeyen (1), güzel davranıs sergileyen (1)” ikinci uygulama sonucunda ifade edilmemiştir. "İyi insan (7/11)” özelliğinin ifade ediliş sıklığ 1 ise kısmen artmıştır. Hz. Muhammed (sav)'in etkinlikler öncesi uygulamada ifade edilmeyen karakter özelliklerinden; "bilgiye önem verirdi (20), hayvanlart ve doğayı severdi (18), danışarak iş yapardı (15), zamanı iyi değerlendirirdi (15), insanlara değer verirdi (14), hiç kimsenin kalbini kırmazdı (8), kötü söz söylemez (6)" ifadeleri etkinlikler sonrasında oldukça yüksek bir sıklıkla ifade edilmiştir. Yine ön uygulamada bahsedilmeyen; "dinine önem verirdi (3), nerede nasıl davranacă̆ını bilirdi (3), örnek hareketleri vardı (2), normal insan (2), vicdanlı (2), bizleri sever kollardı (2), ön yargılı değil (2), her şeye olumlu bakar (2), problem çözen (1), iyinin yanında (1), görgülü (1)” gibi 
başlıca karakter özellikleri de etkinlikler sonrasında ifade edilmiştir. Aşağıda Hz. Muhammed'in (sav) karakter özelliklerine dair öğrenci söylemlerine yer verilmiştir.

\begin{tabular}{|c|c|}
\hline Etkinlik Öncesi Söylem Örnekleri & Etkinlik Sonrası Söylem Örnekleri \\
\hline 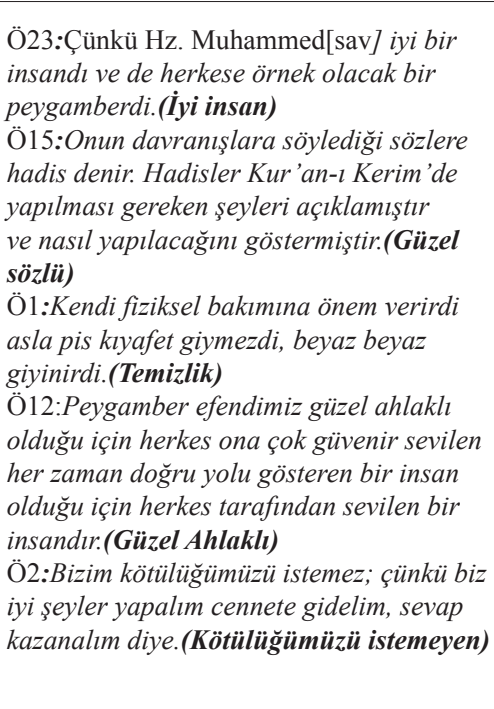 & 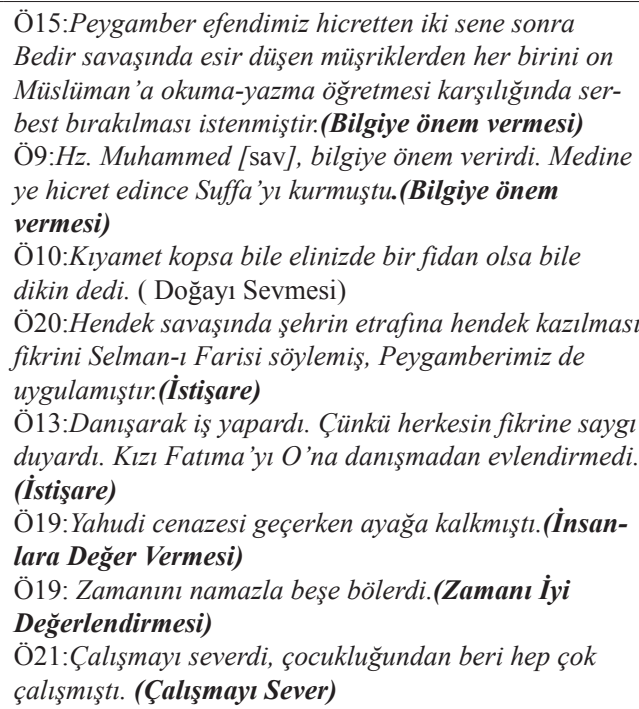 \\
\hline
\end{tabular}

Söylem örnekleri incelendiğinde; etkinlik öncesinde öğrenciler Hz. Muhami med (sav) hakkındaki karakter özelliklerine vurgularken, genel bir çerçevede hareket etmişlerdir. Ancak etkinlik sonrasında O'nun hayatından yaşanmış örnekler vererek karakter özelliğinin uygulanabilir yönüne odaklanmışlardır.

\section{Hz. Muhammed (sav) ile ilişkilendirilen İslam'a ait şart ve semboller tema-}

sı. Aşağıdaki tablo da Hz. Muhammed (sav) ile ilişkilendirilen İslam'a ait şart ve sembollere dair ön uygulama ve son uygulama da elde edilen veriler karş1laştırılarak gösterilmiştir. 


\begin{tabular}{|c|c|c|c|c|c|c|c|}
\hline \multicolumn{4}{|c|}{ Ön uygulama } & \multicolumn{4}{|c|}{ Son uygulama } \\
\hline Algi & Özellikler & Sıklık & Toplam & Alg1 & Özellik & Siklık & Toplam \\
\hline \multirow{25}{*}{ 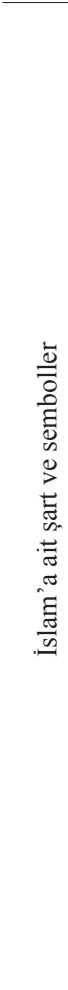 } & Peygamber & 11 & \multirow{25}{*}{38} & \multirow{25}{*}{ 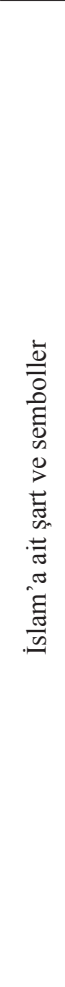 } & Namaz & 11 & \multirow{25}{*}{88} \\
\hline & Kuran-1 Kerim & 11 & & & Kuran-1 Kerim & 11 & \\
\hline & İman & 2 & & & Ahiret & 9 & \\
\hline & Hacca gitmek & 2 & & & Peygamber & 7 & \\
\hline & Namaz & 2 & & & Sevap & 7 & \\
\hline & Zekât & 1 & & & Helal & 6 & \\
\hline & Mübarek kul & 1 & & & Günah & 6 & \\
\hline & Allah'ın kulu & 1 & & & Haram & 6 & \\
\hline & Müslümanlığı öğreten & 1 & & & Cennet & 4 & \\
\hline & Hira mağarası & 1 & & & Cennetle müjdelenmiş kişi & 3 & \\
\hline & İbadetler & 1 & & & Mucize & 3 & \\
\hline & Mucize & 1 & & & İmanın şartlarına uyar & 2 & \\
\hline & Ahiret & 1 & & & İslam'ın şartlarına uyar & 2 & \\
\hline & İslam & 1 & & & Cehennem & 2 & \\
\hline & Oruç & 1 & & & Hadis & 2 & \\
\hline & & & & & Ayet & 2 & \\
\hline & & & & & Mekke & 1 & \\
\hline & & & & & Medine & 1 & \\
\hline & & & & & Müslüman'dı & 1 & \\
\hline & & & & & Hira mağarası & 1 & \\
\hline & & & & & Nurdağ 1 & 1 & \\
\hline & & & & & Secde & 1 & \\
\hline & & & & & Kâbe & 1 & \\
\hline & & & & & Putlara tapmaz & 1 & \\
\hline & & & & & Ezan & 1 & \\
\hline
\end{tabular}

Tablo 4 incelendiğinde, ön uygulamada öğrencilerin Hz. Muhammed (sav) denilince akıllarına gelen İslam'a ait 15 şart ve sembolle (peygamber, Kuran-ı Kerim, iman, hacca gitmek, namaz klmak, zekât, mübarek kul, Allah' 'n kulu, Müslümanlı̆̆ öğreten, Hira Mağarası, ibadetler, mucize, ahiret, İslam, oruç) ilişki kurdukları görülmüştür. Etkinlikler sonrasında ise toplamda İslam'a ait 25 şart ve sembole (namaz, Kuran Kerim, ahiret, peygamber, sevap, helal, günah, haram, cennet, cennetle müjdelenmiş kişi, mucize, imanın şartlarına uyar, İslam'in şartlarına uyar, cehennem, hadis, ayet, Mekke, Medine, putlara tapmaz, Müslüman, Hira mağarası, Nur Dağı, secde, Kâbe, ezan) sıklıklar artarak vurgu yapılmıştır. Uygulamalar karşılaştırıldığında ifadelerin vurgulanma sıklığı, son uygulamada neredeyse iki katından $(38 / 88=2,31)$ fazladır. İslam'a ait şart ve sembollerden "Peygamber, Kur'an-ı Kerim, iman, İslam, namaz, Hira mağarası, mucize, ahiret" kavramlarına her iki uygulamada da yer verilmiştir. Elde edilen veriler oransal olarak değerlendirildiğinde ise "Kuran-ı Kerim (11/11), Hira mağarası (1/1), mucize (1/3), iman (2/2), İslam (1/2)" kavramları neredeyse eşit şekilde 
vurgulanırken "namaz (2/11), ahiret (1/9)" kavramlarının ifade edilme sıklığ1 artış göstermiş̧tir. Peygamber(11/7) kavramının ise ön uygulamaya göre vurgulanma sıklığının düştüğü görülmüştür. Öte yandan "Hacca gitmek (2), zekât (1), mübarek kul (1), Müslümanlı̆̆ı ögreten (1), ibadetler (1), oruç (1)” kavramlarına ise ön uygulama da yer verilirken son uygulamada vurgu yapılmamıştır. Öğrencilerin etkinlikler sonrası yapılan uygulamada ifade ettikleri "sevap (7), helal (6), günah (6), haram (6) " kavramları ilk uygulamada ifade edilmezken ikinci uygulamada yüksek sıklıkla ifade edilmiş̧ir. Yine "cennet (4), cennetle müjdelenmiş kişi (3), cehennem (2), ayet (2), hadis (2), putlara tapmaz (1), Mekke (1), Medine (1), Müslüman'dl (1), Nur Dağı (1), secde (1), Kâbe (1), ezan (1) " kavramları ilk uygulama da ifade edilmeyip ikinci uygulamada belirtilen kavramlardır. Konuyla ilgili söylem örnekleri aşağıda verilmiştir.

\begin{tabular}{|c|c|}
\hline Etkinlik Öncesi Söylem Örnekleri & Etkinlik Sonrası Söylem Örnekleri \\
\hline 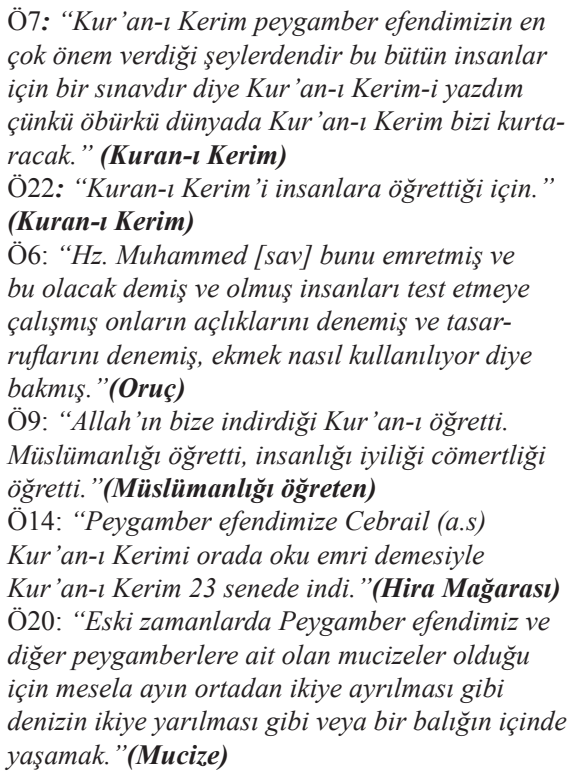 & 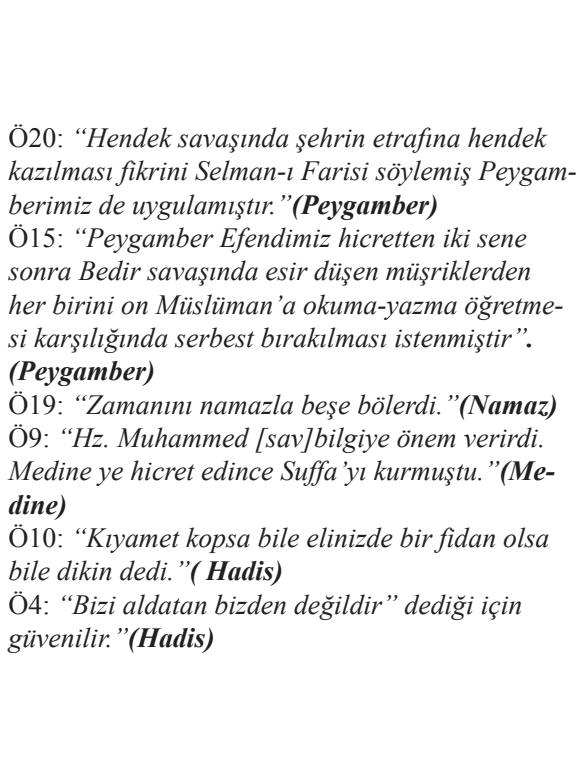 \\
\hline
\end{tabular}

Söylem örneklerinde de görüldüğü üzere, etkinlik öncesinde Ö7'nin Kur'an-1 Kerim'i Hz. Muhammed (sav)'in yazdığ 1 ve Ö6'nın da orucu, Hz. Muhammed (sav)'in emrettiği gibi yanlış bir algıya sahip oldukları, Allah'ın emirlerini ve yaptıklarını Hz. Muhammed'e (sav) atfettikleri görülmüştür. Ö22, Ö9, Ö14, Ö20 kodlu öğrenciler etkinlik öncesinde Hz. Muhammed (sav) ile ilişkilendirdikleri İslam'a ait şart ve sembolleri genel çerçevede değerlendirmişlerdir. Etkinlik sonrası söylem örneklerinde ise söylemleri içinde İslam'a ait şart ve sembolleri doğru anlamlarıyla kullandıkları görülmüştür. Aynı zamanda etkinlik sonrasında Hz. Muhammed (sav)'in hadislerinden de örnekler verebilmişlerdir. 
Hz. Muhammed'in (sav) fiziksel özellikleri teması. Aşağıda Hz. Muhammed (sav)'in fiziksel özelliklerine dair ön uygulama ve son uygulama da elde edilen veriler karşılaştırılarak yer verilmiştir.

Tablo 5: Öğrencilere göre Hz. Muhammed'in (sav) Fiziksel Özellikleri

\begin{tabular}{|c|c|c|c|c|c|c|c|}
\hline \multicolumn{4}{|c|}{ Ön uygulama } & \multicolumn{4}{|c|}{ Son uygulama } \\
\hline Algi & Özellik & Sıklık & Toplam & Algi & Özellik & Sıklık & Toplam \\
\hline \multirow{3}{*}{$\begin{array}{l}\text { Fiziksel } \\
\text { özellikleri }\end{array}$} & Güzel yüzlülük & 4 & \multirow{3}{*}{5} & \multirow{3}{*}{$\begin{array}{l}\text { Fiziksel } \\
\text { özellikleri }\end{array}$} & Güzel & 3 & \multirow{3}{*}{8} \\
\hline & Alnının güzelliği & 1 & & & Güler yüzlü & 3 & \\
\hline & & & & & Zeki & 2 & \\
\hline
\end{tabular}

Tablo 5 incelendiğinde; vurgulanma sıklıkları fazla olmamakla beraber öğrencilerin her iki uygulamada da Hz. Muhammed (sav)'in fiziksel özelliklerine dair kavramlara değindikleri görülmüştür. Ön uygulama da Hz. Muhammed (sav)'in 2 fiziksel özelliğine (güzel yüzlülük, alnının güzelliği) değinilirken, yapılan etkinliklerden sonra 3 fiziksel özelliğine (güzel, güler yüzlü, zeki) vurgu yapılmıştır. Her iki uygulama oransal olarak değerlendirildiğinde Hz. Muhammed'in (sav) güzelliğine ilişkin kavramlardan "güzel yüzlülük (4), alnının güzelliği (1), güzel (3)" neredeyse eşit şekilde ifade edildiği gözlemlenmiştir. Öte yandan ön uygulamada farklı olarak son uygulama da "güler yüzlü (3), zeki (1)" kavramlarına da değinilmiştir. Aşağıda konuya ilişkin öğrenci söylemine yer verilmiştir.

Etkinlik Öncesi Söylem Örnekleri

4:Alnının güzelliği geliyor aklıma. Söylenenlere göre Peygamber efendimizin alnında bir nur varmış. Bende alnında nur olan kimseyi görmediğim için merak ederim.(Alnının güzelliği)

\section{Etkinlik Sonrası Söylem Örnekleri}

Ö9:Hz. Muhammed [sav] bilgiye önem verirdi. Medine'ye hicret edince Suffa'yı kurmuştu. (Zeki)

Ö15:Peygamber efendimiz hicretten iki sene sonra Bedir savaşında esir düşen müşriklerden her birini on Müslüman'a okuma-yazma ögretmesi karşılığında serbest bırakılması istenmiştir. (Zeki)

Ö22:Farklı din sahiplerine kızıp bağırmazdı güler yüzle anlatırdı. (Güler Yüzlü)

Ö4 adlı öğrencinin söyleminden hareketle, etkinlik öncesi Hz. Muhammed (sav)'in şemaili (fiziki görünüşü) hakkında bilgi sahibi olduğu ve bu bilginin öğrencide merak uyandırdığ 1 anlaşılmaktadır. Etkinlik sonrası Ö9 ve Ö15'in görüşlerinde Hz. Muhammed (sav)'in okuma-yazma konusunda öngörülü davranmasından hareketle, zeki olmasına vurgu yaptıkları görülmüştür. Yine Ö22, Hz. Muhammed (sav)'in farklı din mensuplarıyla ilişkisinde güler yüzlü olduğunu açık bir şekilde ifade etmiştir. 
Hz. Muhammed'in (sav) Allah ile olan ilişkisi teması. Aşağıda öğrencilere göre Hz. Muhammed (sav)'in Allah ile olan ilişkisi yer almaktadır. Öğrenciler ilk uygulamada Hz. Muhammed (sav)'in Allah ile olan ilişkisine değinmediklerinden dolayı tablo 6 da son uygulamaya ait bulgular gösterilmiştir.

Tablo 6: Hz. Muhammed'in Allah (sav) ile Olan İlişkisi

Son uygulama

\begin{tabular}{|c|c|c|c|}
\hline Algı & Özellik & Sıklık & Toplam \\
\hline \multirow{5}{*}{ 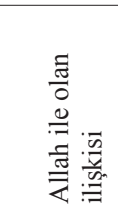 } & Allah'1 çok severdi & 3 & \multirow{5}{*}{11} \\
\hline & Dua etmesini sever & 3 & \\
\hline & Allah'a asla karşı gelmezdi & 2 & \\
\hline & Allah'ın varlığına ve birliğine inanır & 2 & \\
\hline & Allah'a yardımcı oldu & 1 & \\
\hline
\end{tabular}

Tablo 6 incelendiğinde yapılan etkinliklerden sonra vurgulanma sıklıları çok yüksek olmamakla beraber Hz. Muhammed (sav)'in Allah ile olan ilişkisi hakkında "Allah'ı çok severdi (3), dua etmesini sever (3), Allah'a asla karşı gelmezdi (2), Allah'ın varllğına ve birliğine inanır (2), Allah'a yardımcı oldu (1) " şeklinde ifadeler kullanılmıştır. Öğrenciler bu konuyla ilgili söylem örnekł lerinde bulunmamışlardır.

Hz. Muhammed (sav) ile bağlantısı kurulan diğer kavramlar teması. Aşă̆1da ön uygulama ve son uygulama da elde edilen Hz. Muhammed (sav) ile bağlantısı kurulan diğer kavramlara ait bulgulara karşılaş̧ırılarak yer verilmiştir.

\begin{tabular}{|c|c|c|c|c|c|c|c|}
\hline \multicolumn{4}{|c|}{ Ön uygulama } & \multicolumn{4}{|c|}{ Son uygulama } \\
\hline Alg1 & Özellik & Sıklık & Toplam & Algı & Özellik & Sıklık & Toplam \\
\hline \multirow{4}{*}{ 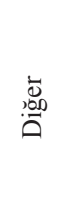 } & Yetim & 4 & \multirow{4}{*}{7} & \multirow{4}{*}{ 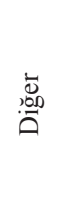 } & Cahiliye & 3 & \multirow{4}{*}{7} \\
\hline & Korku & 1 & & & Okur-yazar & 2 & \\
\hline & Dünya & 1 & & & Halkçıydı & 1 & \\
\hline & $\begin{array}{c}\text { Eski zamanlardaki } \\
\text { yoksulluk }\end{array}$ & 1 & & & Hürriyetçiydi & 1 & \\
\hline
\end{tabular}

Tablo 7 incelendiğinde öğrencilerin etkinlik öncesinde, Hz. Muhammed (sav)'i; “yetim, korku, dünya, eski zamanlardaki yoksulluk” kavramlarıyla ilişkilendirdikleri görülmüştür. Etkinlikler sonrasında ise "cahiliye, okur-yazar, halkçıydı, hürriyetçiydi" kavramlarını ifade etmişlerdir. Verilerden hareketle etkinlik öncesi ve sonrası ifade edilen kavramların aynı olmadığ1 görülmüştür. Kavramların vurgulanma sıklıkları oransal olarak değerlendirildiğinde her iki uygulamada da (7/7) eşit olduğu görülmüştür. Ayrıca ilk uygulama da ifade edilen "yetim (4)" ve ikinci uygulamada ifade edilen "cahiliye (3) "kavramı belirgin bir sıklıkla vurgulanmıştır. Öte yandan ilk uygulamada "korku (1), dünya (1), eski 
zamanlardaki yoksulluk (1)", ikinci uygulamada ise "okur-yazar (2), halkçıydl (1), hürriyetçiydi (1)" kavramları da öğrenciler tarafindan az bir sıklıkla ifade edilmiştir. Öğrenciler bu konuyla ilgi söylem örneğinde bulunmamışlardır.

Ön uygulama ve son uygulamada elde edilen temalar karşılaştırılarak oluşturulan tablolar genel olarak incelendiğinde, öğrencilerin Hz. Muhammed (sav)'e yönelik ön uygulamada elde edilen algıları ile etkinlikler sonrası Hz. Muhammed (sav) algıları arasında belirgin farklılıklar görülmüş̧ür.

\section{Hz. Muhammed'in (sav) beşer olma algısı}

Uygulanan etkinliklerden sonra öğrencilerden; “ De ki: Ben de ancak sizin gibi bir beşerim (insanım)" (Fussilet/6) ayeti kerimesini yorumlamaları istenmiştir. Öğrencilerin hemen hemen hepsinin, Hz. Muhammed (sav)'in hem bir insan hem de bir peygamber olarak örnek davranışlar sergilediği ve insani özelliklere sahip olduğunu vurguladıkları görülmüştür. Ayrıca öğrencilerin çoł ğunun, O'nun sergilediği davranışları bizlerinde sergileyebileceği yönünde dün şünceye sahip oldukları tespit edilmiştir. Etkinliğe yönelik öğrenci söylemlerine aşağıda yer verilmiştir.

\begin{tabular}{|c|c|}
\hline Öğrenci & Söylemler \\
\hline Ö1 & $\begin{array}{l}\text { Şöyle demek istiyor: Bende sizler gibi, Müslüman'ım sizlere değer veririm, bilgiye önem } \\
\text { veririm, hakk gözetirim, doğayl ve hayvanlart severim, çalışmayl sever, zamanı iyi değer- } \\
\text { lendiririm. Merhametli ve affediciyim, danışarak iş yapmayl severim. }\end{array}$ \\
\hline Ö2 & $\begin{array}{l}\text { Ben de sizin gibiyim. Ben de insanım ben de sizin gibi yürüyorum, benimde gözlerim var, } \\
\text { ağzım var. Sizin gibi bir insanım Peygamber Efendimiz görünmeyen bir varllk değildi. Bi- } \\
\text { zim gibi insandl. }\end{array}$ \\
\hline Ö3 & $\begin{array}{l}\text { Bizler de Peygamberimiz gibi adaletli oluruz. İnsanlarda Peygamberimiz gibi merhametli } \\
\text { ve hoşgörülü olur, bizler de Peygamberimiz gibi çalışmayl sever zamanı iyi değerlendiririz. }\end{array}$ \\
\hline Ö5 & $\begin{array}{l}\text { Peygamber efendimiz bizim gibi yer, içer, giyer, her türlü ihtiyacını giderirmiş. Eğer öyle } \\
\text { olmasaydı, Hıristiyanlar Peygamberimizi (sav)büyücü olarak görürlerdi. }\end{array}$ \\
\hline Ö7 & $\begin{array}{l}\text { Ben de sizin gibi bir insanım sizinle aynlyım. Yediŭim içtĭgim aynı. Sizin gibi yaşarım size } \\
\text { çok benzerim. Seninle aynlyım. }\end{array}$ \\
\hline Ö8 & $\begin{array}{l}\text { Ayette diyor ki; bende sizin gibi bir insanım sizde benim gibi olabilirsiniz. Ben de sizin gibi } \\
\text { doğruyu yanlşsı ayırt edebilirim. }\end{array}$ \\
\hline Ö10 & $\begin{array}{l}\text { O da bir insan. Hz. Muhammed (sav) istersek bizde onun kadar olmasa da iyi biri olabiliriz. } \\
\text { Çünkü bizde insanız. O da aramızda fark yok farklı olarak Onun görevi var; İslamiyet'i } \\
\text { yaymak. }\end{array}$ \\
\hline Ö12 & $\begin{array}{l}\text { Peygamber Efendimiz bir melek veya görünmeyen bir varlık değildi. Bizim gibi bir insandl. } \\
\text { Peygamber efendimiz gibi güzel ahlakl, dürüst adaletli, merhametli ve birçok sayamad- } \\
\text { ğım davranışlarını sergilememizi anlatmaktadır. Peygamber efendimiz gibi güzel ahlaklı } \\
\text { olmaya çalışmamızı anlatır. }\end{array}$ \\
\hline Ö14 & $\begin{array}{l}\text { Bende sizin gibi bir insanım doğruyu yanlışı ayırt edebiliyorum. Birbirinize iyi davranın } \\
\text { hakkını yemeyin iyiye ve güzele yöneltin her sorunu kavgayla çözmeyin ilk önce merhamet } \\
\text { ve şefkatle uyarın davranışlarınızda ve işlerinizde beni örnek alın. }\end{array}$ \\
\hline
\end{tabular}


Ö20 Burada Hz. Muhammed (sav) bize, bizim gibi bir insan olduğunu söylemek istiyor yani bizde onun gibi olabiliriz diyor. Yani bizde iyi ve güzel davranışlar sergileyebiliriz.

Söylem örneklerinde de görüldüğü üzere öğrencilerin hepsinin ayetten $\mathrm{Hz}$. Muhammed (sav)'in görünmeyen bir varlık (Ö2) ve büyücü (Ö5) olmadığ1, bizim gibi bir insan olduğu yargısını çıkardıkları görülmektedir. Öte yandan Hz. Muhammed (sav)'in insanlardan farklı olarak tebliğ görevinin bulunduğu (Ö10) belirtilmiştir. Yine öğrencilerin çoğunluğunun Hz. Muhammed (sav)'in örnek davranışlarına ve yaşamında sergilemiş olduğu değerlere vurgu yaptıkları görülmektedir. Sergilemiş olduğu örnek davranışları bizlerinde yapması gerektiği bunun çok da zor olmadığı vurgusu ise öğrenciler tarafından sıklıkla yapılmıştır.

\section{Toplumsal Sorunları Çözme Bağlamında Örnek İnsan Olarak Hz. Muhammed (sav)}

Hz. Muhammed (sav) ile ilgili örnek bir insan olarak toplumsal sorunları çözme bağlamında süreç içerisinde üç etkinlik uygulanmıştır. Poster etkinliği öncesi çevrelerinde olan olaylara bakış açısı kazandırmak amacıyla sorun ağacı etkinliği uygulanmıştır. Ardından poster etkinliği uygulanmıştır. Etkinlik sonrasında ise öğrencilerden sırayla, Hz. Muhammed (sav)'in çözüm önerisi ve kendi çöł züm önerileri alınmıştır.

Öğrenciler, Hz. Muhammed (sav)'in kendisinden daha makul bir şekilde yaklaşarak, kendisiyle aynı şekilde davranarak, kendisinden daha sert ceza vererek problemi çözeceğini söyleyerek üç tür yol izlemişlerdir. Etkinlik öncesi kendi çözüm önerileri, etkinlik sonrası Hz. Muhammed (sav)'e ait olacağını düşündükleri çözüm önerileri ve yine etkinlik sonrasında Hz. Muhammed (sav) ile özdeşim kurarak kendi sundukları çözüm önerilerine yönelik bulgulara aşağıda yer verilmiştir.

\section{Probleme Hz. Muhammed (sav)'in kendisinden daha makul bir şekilde yaklaşacağını ifade edenler}

Aşağıda Hz. Muhammed (sav)'in problemi kendisinden daha makul bir şekilde yaklaşarak çözeceğini ifade eden öğrencilerin söylemlerine yer verilmiştir. 


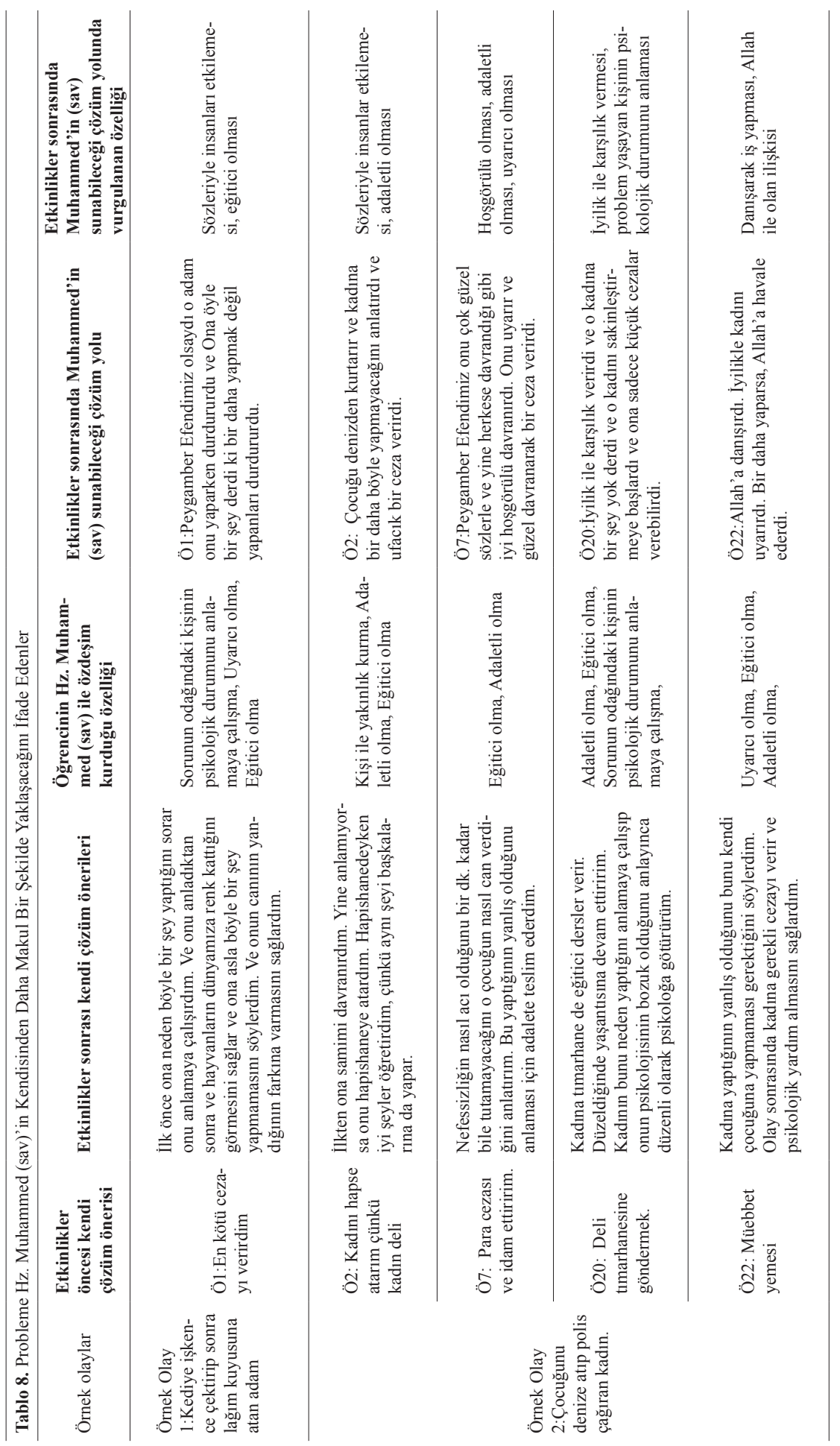




\begin{tabular}{|c|c|c|c|c|c|}
\hline 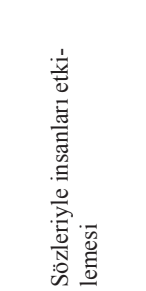 & 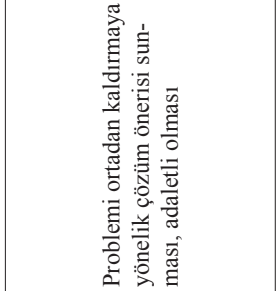 & 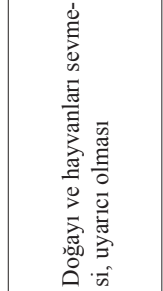 & 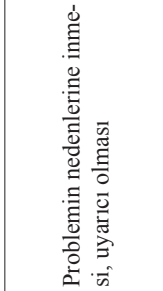 & 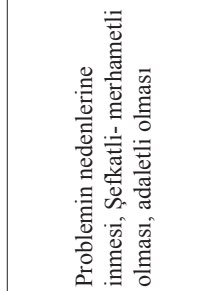 & 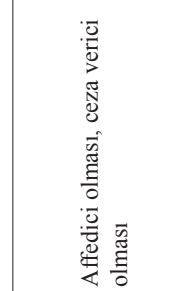 \\
\hline 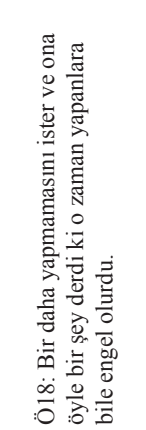 & 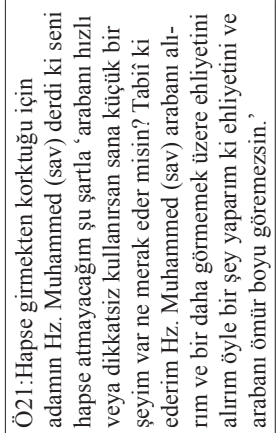 & 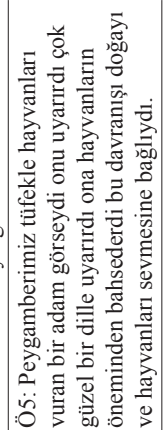 & 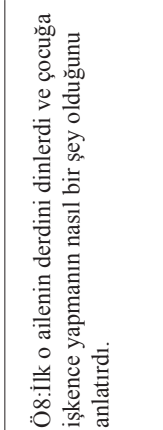 & 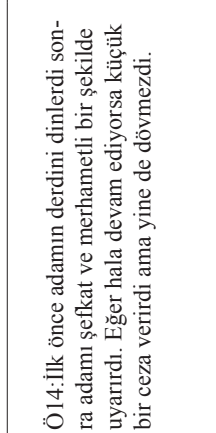 & 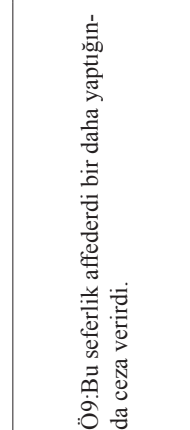 \\
\hline 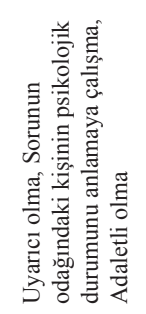 & 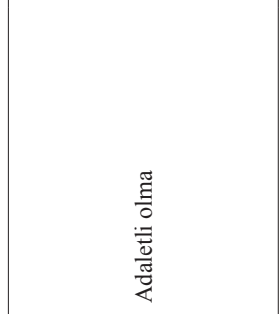 & 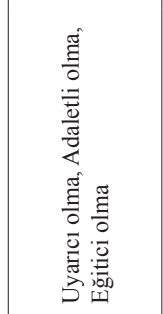 & 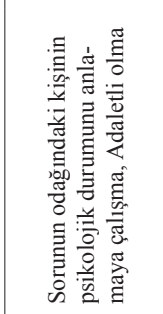 & 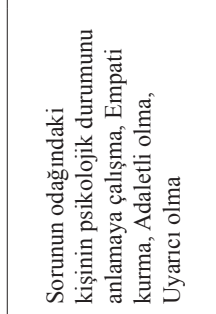 & 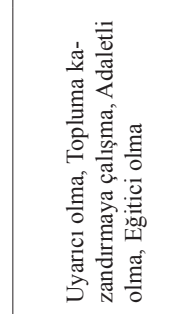 \\
\hline 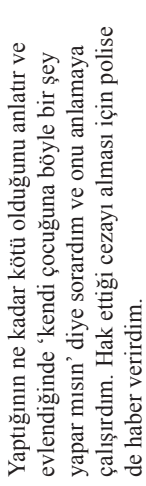 & 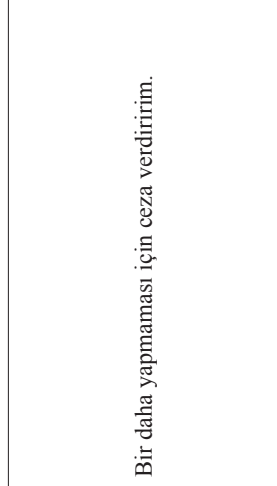 & 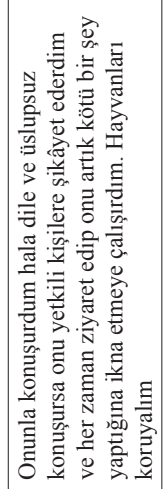 & 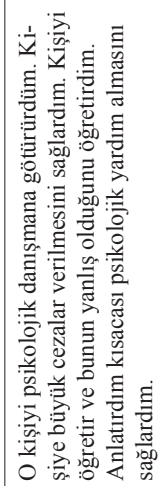 & 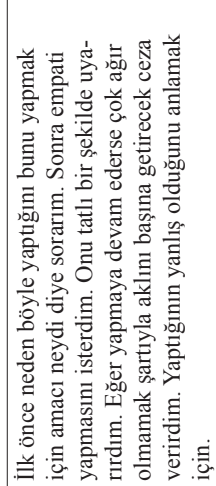 & 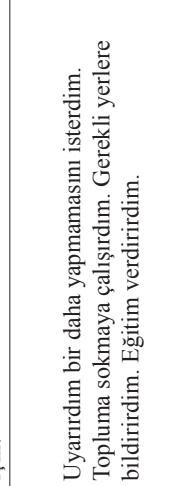 \\
\hline 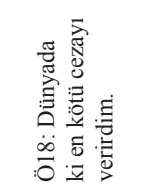 & 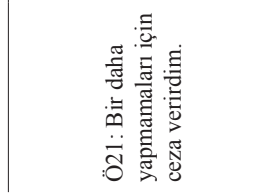 & 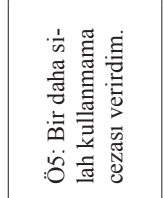 & 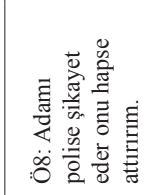 & 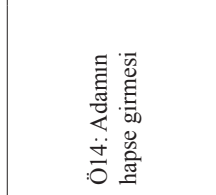 & 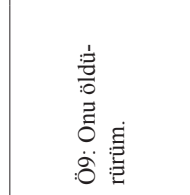 \\
\hline & 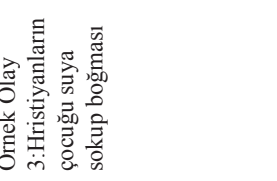 & 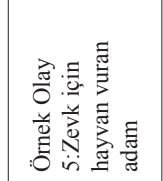 & & 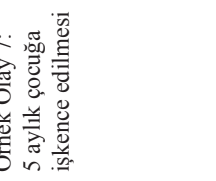 & 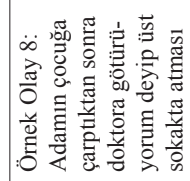 \\
\hline
\end{tabular}




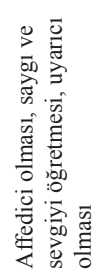

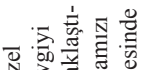

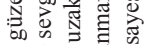
总窟焉奇言

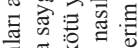

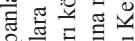

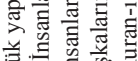

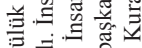

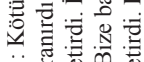

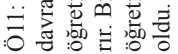
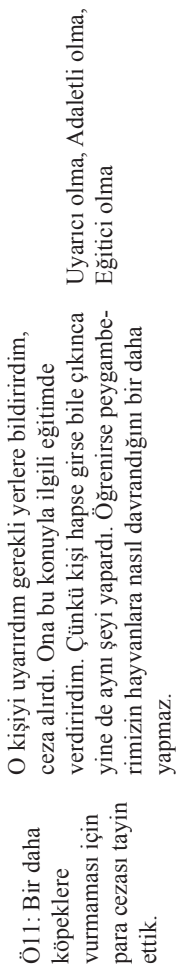

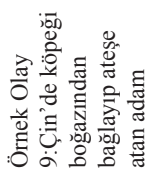

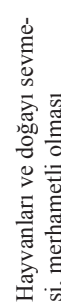

表焉

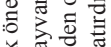

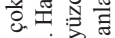

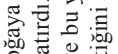

政

号春

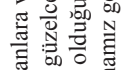

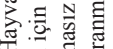

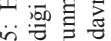

学焉扂:

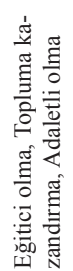

遥䓌

递 웜

흘

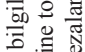

曋

尊

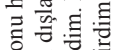

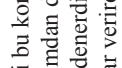

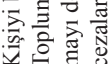

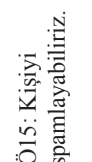

点

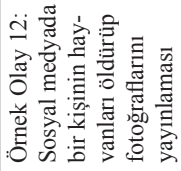

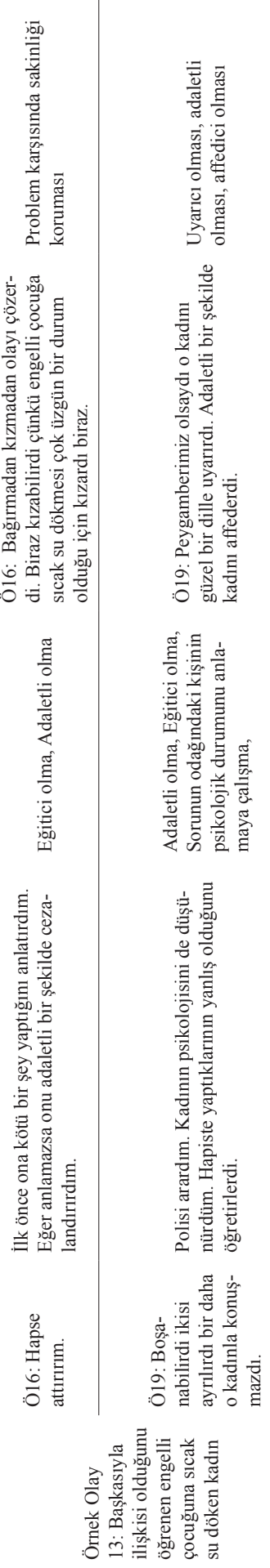


Söylemler incelendiğinde öğrencilerin büyük bir çoğunluğu Hz. Muhammed (sav)'in kendisinden daha makul bir şekilde sorunu çözeceğini ifade etmişlerdir. Öğrencilerin etkinlik öncesi kendi çözüm önerileri genel olarak ceza yöntemine dayanmaktadır. Etkinlikler sonrasında ise öğrencilerin barışçıl olmayan çözüm önerilerinin, Hz. Muhammed (sav)'in şahsiyeti bağlamında değerlendirildiğinde barışç1 (uzlaşımc1) çözümlere dönüştüğü görülmüsştür. Öğrenciler çözüm önerilerinde Hz. Muhammed (sav)'in "sözleriyle insanları etkilemesi(örnek olay;1, 2, 3), hoşgörü̈lü olması(örnek olay; 2), adaletli olması (örnek olay;2, 3, 7, 13), uyarıcı olması (örnek olay; 2, 5, 7, 9, 13), iyilik ile karşılık vermesi(örnek olay;2), problem yaşayan kişinin psikolojik durumunu anlamasl (örnek olay;2), danışarak iş yapması (örnek olay; 2), Allah ile olan ilişkisi (örnek olay;2), problemi ortadan kaldırmaya yönelik çözüm önerisi sunması (örnek olay; 3), doğayl ve hayvanları sevmesi (örnek olay; 5, 12), problemin nedenlerine inmesi (örnek olay; 7), şefkatli- merhametli olması (örnek olay; 7, 12), affedici olması (örnek olay; 8, 9, 13), ceza verici olması (örnek olay; 8), saygl ve sevgiyi öğretmesi (örnek olay; 9), problem karşısında sakinliği koruması (örnek olay; 13) 'karakter özelliklerine vurgu yaptıkları görülmüştür. Etkinlik sonrasında öğrencilerden tekrar çözüm önerisi istendiğinde öğrencilerin Hz. Muhammed (sav)'in çözüm öneriyle paralel çözüm önerileri sundukları tespit edilmiştir. Öğrencilerin etkinlik sonrası kendi çözüm önerilerinde ise Hz. Muhammed (sav)'in “sorunun odă̆ındaki kişinin psikolojik durumunu anlamaya çalışma (örnek olay; 1, 2, 3, 5, 7, 13), uyarıcı olma (1, 2, 3, 5, 7, 8, 9), eğitici olma (örnek olay; 1, 2, 5, 7, 8, 9, 12, 13), kişi ile yakınlık kurma (örnek olay; 1), adaletli olma (örnek olay;1, 2, 3,5, 7, 8, 9, 12, 13), empati kurma(örnek olay; 7), topluma kazandırma (örnek olay;8, 12) karakter özellikleriyle özdeşim kurdukları görülmüştür. 


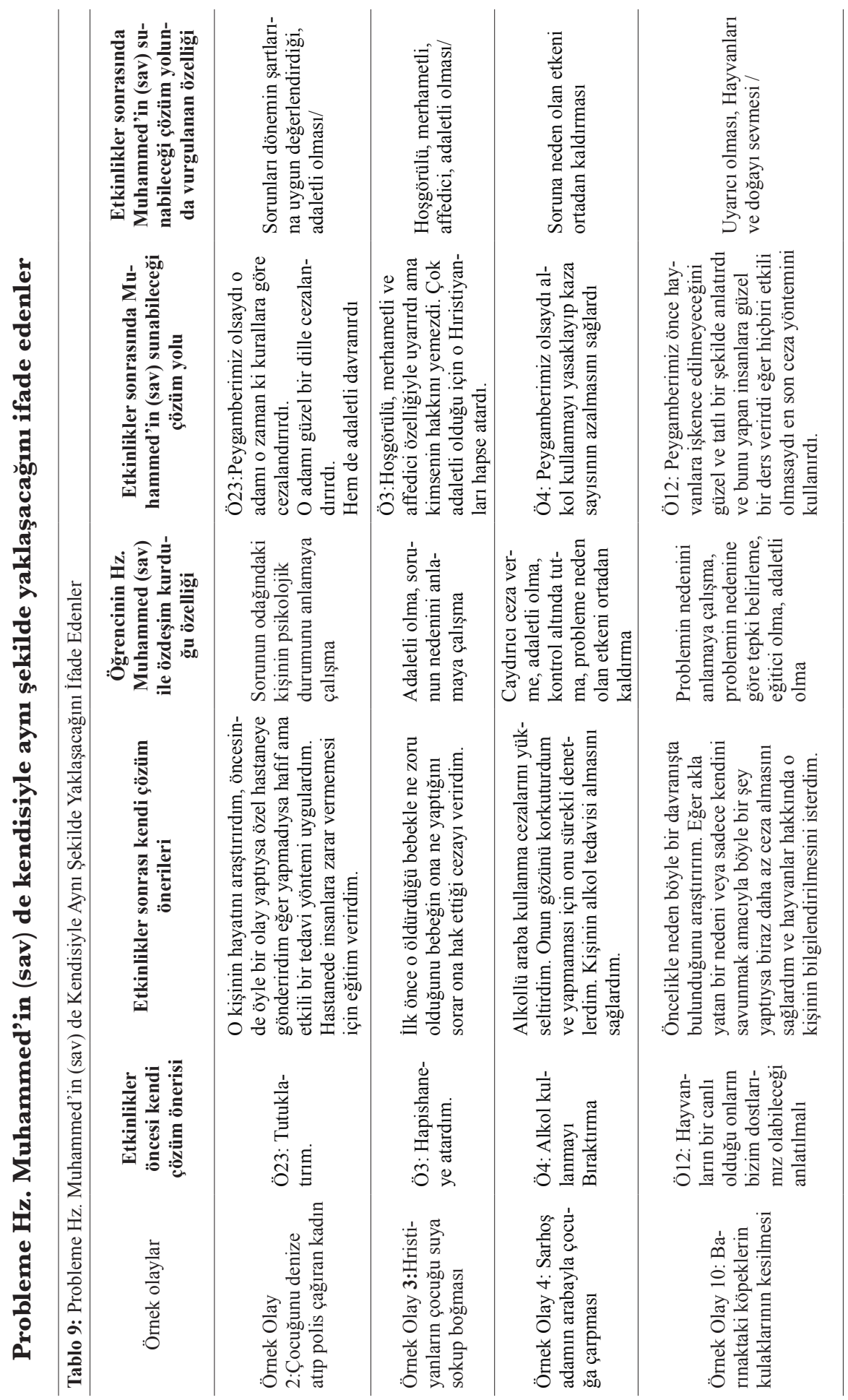


Öğrenci söylemleri incelendiğinde öğrencilerin bir kısmı Hz. Muhammed (sav)'in de kendisi gibi çözüm önerisi sunacağını ifade etmişlerdir. Ö23 ve Ö3, Hz. Muhammed (sav)'in adaletli olduğu için tutuklatacağını dile getirmişlerdir. Öte yandan Ö4 ve Ö12 ise süreç öncesi de soruna neden olan etkenleri ortadan kaldırmaya yönelik daha makul çözüm önerisi sunarken, etkinlikler sonrası Hz. Muhammed (sav)'in de aynı şekilde davranacağını söylemişlerdir. Öğrenciler çözüm önerilerinde Hz. Muhammed (sav)'in "sorunları dönemin şartlarına uygun değerlendirmesi (örnek olay; 2), adaletli olması (örnek olay; 2, 3), hoşgörülü olması (örnek olay; 3), merhametli olması (örnek olay; 3), affedici olması (örnek olay;3 ), soruna neden olan etkeni ortadan kaldırması (örnek olay; 4), uyarıcı olması (örnek olay; 10), hayvanları ve doğayı sevmesi (örnek olay; 10)" karakter özelliklerine vurgu yaptıkları görülmüştür. Yine öğrencilere etkinlikler sonrası kendi çözüm önerilerini sorulduğunda Hz. Muhammed (sav)'in, “sorunun odağındaki kişinin psikolojik durumunu anlamaya çalışma (örnek olay; 2), adaletli olma (örnek olay; $3,4,10$ ), sorunun nedenini anlamaya çalışma (örnek olay; 3,10 ), caydırıcı ceza verme (örnek olay; 4), kontrol altında tutma (örnek olay; 4), probleme neden olan etkeni ortadan kaldirma (örnek olay; 4), problemin nedenine göre tepki belirleme (örnek olay; 10), eğitici olma (örnek olay; 10)" karakter özellikleriyle özdeşim kurdukları tespit edilmiştir.

\section{Probleme Hz. Muhammed (sav)'in kendisinden daha sert tepki vererek yaklaşacağını ifade edenler}

\begin{tabular}{|c|c|c|c|c|c|}
\hline $\begin{array}{l}\text { Örnek } \\
\text { olaylar }\end{array}$ & $\begin{array}{l}\text { Etkinlik- } \\
\text { ler öncesi } \\
\text { kendi çözüm } \\
\text { önerisi }\end{array}$ & $\begin{array}{l}\text { Etkinlikler son- } \\
\text { rası kendi çözüm } \\
\text { önerileri }\end{array}$ & $\begin{array}{l}\text { Öğrencinin Hz. } \\
\text { Muhammed (sav) } \\
\text { ile özdeşim kur- } \\
\text { duğu özelliği }\end{array}$ & $\begin{array}{l}\text { Etkinlikler sonrasında } \\
\text { Muhammed'in (sav) suna- } \\
\text { bileceği çözüm yolu }\end{array}$ & $\begin{array}{l}\text { Etkinlikler } \\
\text { sonrasında Mu- } \\
\text { hammed'in (sav) } \\
\text { sunabileceği çözüm } \\
\text { yolunda vurgula- } \\
\text { nan özelliği }\end{array}$ \\
\hline \multirow{2}{*}{$\begin{array}{l}\text { Örnek Olay } \\
6: \text { köpek } \\
\text { yavrusunu } \\
\text { çuvala ko- } \\
\text { yup denize } \\
\text { atan adam }\end{array}$} & $\begin{array}{l}\text { Ö6: Onu } \\
\text { denize atma- } \\
\text { yıp barınağa } \\
\text { verdirirdim }\end{array}$ & $\begin{array}{l}\text { Amacın ne diye } \\
\text { sorarım. O hayvan } \\
\text { sana ne yaptı } \\
\text { diye sorarım. Ve } \\
\text { en uygun cezayı } \\
\text { verirdim. }\end{array}$ & $\begin{array}{l}\text { Adaletli olması, } \\
\text { problemin } \\
\text { nedenini anlamaya } \\
\text { çalışma }\end{array}$ & $\begin{array}{l}\text { Ö6: O kişiyi çarpardı ve } \\
\text { insansızlıkla suçlar günahla- } \\
\text { rını çoğaltırdı. Tövbe ederse } \\
\text { Peygamber Efendimiz onu } \\
\text { belki affederdi, affetmese } \\
\text { cehennem ateşinde o kişi } \\
\text { yanardı. }\end{array}$ & $\begin{array}{l}\text { Cezalandırıcı olma- } \\
\text { sı, affedici olması, } \\
\text { suçlayıcı olması }\end{array}$ \\
\hline & $\begin{array}{l}\text { Ö10: } \\
\text { Hayvanları } \\
\text { barınağa gö- } \\
\text { türmeli sokak } \\
\text { köpekleri gü- } \\
\text { venli şekilde } \\
\text { yaşayacak }\end{array}$ & $\begin{array}{l}\text { Ağır ceza yerine } \\
\text { o köpeklerin } \\
\text { çığlıklarını, ağla- } \\
\text { malarını annesinin } \\
\text { başında ağlama- } \\
\text { larını ona dinlete } \\
\text { dinlete, izlete } \\
\text { izlete akıllanması- } \\
\text { nı sağlardım. }\end{array}$ & $\begin{array}{l}\text { Empati kurmasını } \\
\text { sağlama }\end{array}$ & $\begin{array}{l}\text { Ö10: Yapanları affeder hoş- } \\
\text { görülü karşılardı. İnsanlara } \\
\text { danışır öyle karar verirdi. } \\
\text { Günah olduğunu anlatır, } \\
\text { cehennemi anlatır ve onlar } \\
\text { korkarak bir daha yapmaz. }\end{array}$ & $\begin{array}{l}\text { Affedici, hoşgörülü, } \\
\text { danışarak iş yapma- } \\
\text { s1, korkutmas1/ }\end{array}$ \\
\hline $\begin{array}{l}\text { Örnek Olay } \\
\text { 11: Uyuyan } \\
\text { köpeğe } \\
\text { tekme atan } \\
\text { kişi }\end{array}$ & $\begin{array}{l}\text { Ö13: Ömür } \\
\text { boyu mü- } \\
\text { ebbet }\end{array}$ & $\begin{array}{l}\text { O adam kamu ce- } \\
\text { zası verip çevreye } \\
\text { duyarlı yaparım. }\end{array}$ & Cezalandırıcı olma & $\begin{array}{l}\text { Ö13: O köpeği vuran adama } \\
\text { öyle kızardı ki ilk önce onu } \\
\text { uyarır eğer dinlemezse ceza } \\
\text { verirdi. }\end{array}$ & $\begin{array}{l}\text { Kızması, uyarıcı } \\
\text { olması, cezalandırıcı } \\
\text { olması/ }\end{array}$ \\
\hline
\end{tabular}


Öğrenci söylemleri incelendiğinde etkinlikler sonrasında öğrencilerin bir kısmı Hz. Muhammed (sav)'in kendisinden daha sert tepki vererek probleme yaklaşacağını ifade etmişlerdir. Öğrencilerin çözüm önerilerinde Hz. Muhammed (sav)'e ait olduklarını düşündükleri "cezalandırıcı olması (örnek olay; 6, 11), suçlayıcı olması (örnek olay; 6), affedici olması (örnek olay; 6), hoşgörülü olması (örnek olay; 6), danışarak iş yapması (örnek olay; 6), korkutması (örnek olay; 6), kızması (örnek olay; 11), uyarıcı olması (örnek olay; 11)" 7 karakter özelliğine vurgu yapmışlardır. Öğrencilerin etkinlikler esnasında farkındalık oluşturmak istenilen karakter özellikleri ve değerlere kısmen değindikleri Ö10’un “Yapanları affeder hoşgörüllü karşılardı. İnsanlara danışır öyle karar verirdi. Günah olduğunu anlatır, cehennemi anlatır ve onlar korkarak bir daha yapmaz.” söylemiyle görülmektedir. Ö6'nın Hz. Muhammed'e (sav) ait olduğunu düşündüğü "O kişiyi çarpardı ve insansızlıkla suçlar günahlarını çoğaltırdl. Tövbe ederse Peygamber Efendimiz onu belki affederdi affetmese cehennem ateşinde o kişi yanardl. " söyleminden hareketle, öğrencinin $\mathrm{Hz}$. Muhammed'e ait düşüncelerinin yanlış olduğu görülmüştür. Öğrencilerin bu yanlış algılarının temelinde informal ortamlarda aldıkları bilgilerin etkisi olduğu söylenebilir. Yine öğrencilerin Hz. Muhammed (sav) ile özdeşim kurarak sunduğu etkinlik sonrası kendi problem çözme becerileri incelendiğinde; "adaletli olma (örnek olay;6), problemin nedenini anlamaya çalı̧̧ma (örnek olay; 6), empati kurmasını sağlama (örnek olay; 6), cezalandırıcı olma (örnek olay; 11)" gibi özelliklerine değindikleri görülmüştür.Öğrencilerin etkinlik öncesi kendi çözüm önerileri ile etkinlik sonrası Hz. Muhammed (sav) ile özdeşleştirdikleri çözüm önerileri farklılık göstermektedir. 21 öğrencinin fikir beyan ettiği çalışmanın bu kısmında etkinlikler sonrasında öğrencilerin incelemiş olduğu örnek olaylardan çıkarımda bulunarak Hz. Muhammed (sav)'e ait kişilik özelliklerini çözüm önerilerine yansıttıkları görülmüştür.

\section{Tartışma, Sonuç ve Öneriler}

Bu çalışma ile 8. sınıf öğrencilerinin, kendilerine "rol model" olarak sunulan bireylerin örnek davranışlarını analiz ederek, hayatlarında karşılaştıkları durumlara değerler penceresinden bakabilmelerini amaçlamaktadır. Rol model olarak Hz. Muhammed (sav) ile ilgili bir takım etkinlikler yapılmış ve bunların sonucunda öğrencilerin peygamber efendimize dair algılarının zenginleştiği ve O'nu örnek aldıkları görülmüştür. 8. Sınıf öğrencilerinin ön uygulamada, Hz. Muhammed (sav) için; “Allah'ın kulu, Müslümanlı̆̆ı öğreten, Kur'an-1 Kerim, 
peygamber" gibi çağrışımlarının yanı sıra; uygulama sonrasında "güvenilir olma, adaletli, hoşgörülü, sabırll, cesaretli, çalışkan, merhametli, saygıll, barlşsever (uzlaşmacı), bilgiye önem veren, danışarak iş yapan, insanlara değer veren" gibi peygamber efendimizin sahip olduğu pek çok değer ve karakter özelliğini dile getirdikleri tespit edilmiştir.

Hz. Muhammed (sav)'in sahip olduğu değerler temasında, en yüksek sıklıkla (2/22) dile getirilen değer "güvenilir bir insan" olmasıdır. Bu durumun nedeni, güvenilir olma değerinin aslında tüm değerlerin uygulanma noktasında mihenk taş1 görevi görmesi olabilir. Arslan (2017)'ın çalışmasında dile getirdiği gibi insanların güven temelinde bir yaşam sürebilmesiyle, toplumsal huzurun sağlandığı bir dünya oluşur. Çünkü güven, değerlerin oluşmasına ve uygulanmasına vesile olmaktadır. Sarıçam (2006)'ın “evrensel değerler insanların birbirine güvenini sağlamak ve güven ortamı oluşturmak için belirlenmiş normlardır" şeklindeki ifadesi güvenin önemini göstermektedir. Öğrenciler tarafından da Hz. Muhammed (sav)'in güvenilir olmasına (el-Emin) yapılan vurgu çokluğunun nedeni; merhamet, adalet, saygı, sabır, cesaret gibi pek çok değeri yaşantısına aktaran yani söylediğini yaşayan bir insana duyulan inanç ve güvendir.

Bireylerin hayatlarında karşılaştıkları durumlara karşı duyarlı olmaları değerler eğitiminin en temel amaçlarındandır. Bireyin sahip olduğu değerler, gelecekte olaylara bakış açısını, kişiliğini belirleyeceği için hayati öneme sahiptir. Bu nedenle değerleri kazanması ve içselleştirmesi gerekir (Yaman, 2014). Çalışmada da öğrencilerin güvenilir olma değerinden sonra en fazla vurguladıkları değer "Adalet”tir. Adalet değerinin vurgulanma sıklığının fazla (3/21) olmasının nedeni, Hz. Muhammed (sav)' in bulunduğu şartlara uygun olan en iyi davranış1 seçtiğini ve sergilediğini gözlemlemeleri olabilir. Adaletin sadece ceza vermek olarak algılanması yanlıştır. Tarhan (2016)'a göre adalet; insanın bir durum karşısında göstermiş olduğu felsefi tavırdır. Adalet yapılan yanlışı sadece cezalandırmak değil, iyilikleri artırarak gerçekleştirilmesidir. Yine ilk çalışmada hiç vurgulanmayan hoşgörü değeri, etkinlikler sonrasında yüksek bir sıklıkla (0/22) ifade edilmiştir. Yine çalışmanın bu kısmında Hz. Muhammed (sav)'in; sabırlı (4/19), cesaretli (0/18), çalışkan(0/17), merhametli (2/16), affedici (1/13) olması değerlerinin vurgulanma sıklıklarının da arttığı tespit edilmiştir. Bu durum bizlere öğrencilerin Hz. Muhammed (sav)'in örnek davranışları üzerinden vurgulanan değerlerin farkına vardıklarını göstermektedir.

Geleceğini düşünen bir toplum, iyi ahlaklı ve karakter sahibi bireyler yetiştirmelidir. Ahlaki karakter bireyin bulunduğu toplumun, değer yargılarını içsel- 
leştirerek hiçbir baskı ve zorlama hissetmeden iyi olanı, davranışlarında sergilemesi halidir (Hökelekli, 2009). Bu çalışmada da Hz. Muhammed (sav)'in karakter özellikleri temasında öğrencilerin süreç öncesinde belirttikleri; "güzel sözlü, ağırbaşll" kavramları uygulamaya dönük değer içeren davranışlar olarak nitelendirilebilecekken; "iyi insan, en iyi dost/arkadaş, güzel ahlakll, kötülügüumüzü istemeyen, güler yüzlü, temizlik, güzel davranış sergileyen” gibi uygulamaya dönük olmayan, genel olarak ifade edilen kavramlar yüksek sıklıkla vurgulanmıştır. Etkinlikler sonrasında öğrencilerin söylemleri; "bilgiye önem verirdi, hayvanları ve doğayı severdi, danışarak iş yapardl, zamanı iyi değerlendirirdi, insanlara değer verirdi, iyilik meleği/iyi insan, hiç kimsenin kalbini kırmazdı, kötü söz söylemez, dinine önem verirdi, nerede nasıl davranacă̆ını bilirdi, örnek hareketleri var, iyi arkadaş, normal insan, vicdanl, bizleri sever kollardl, ön yargılı değil, her şeye olumlu bakar, ağırbaşll, problem çözen, iyinin yanında, güzel ahlakll, görgülü" gibi söylemlere dönüşmüştür. Bu sonuç öğrencilerin, değerlerin davranışlarla kendini gösterdiğini anlamlandırdıklarını göstermektedir. Öğrenciler tarafından iyi insan ve güzel ahlaklı kavramlarının neleri kapsadığı Hz. Muhammed (sav)'in karakter özellikleriyle detaylandırılarak ifade edilmiştir. Söylemlerin bu derece zenginleşmesi Hz. Muhammed (sav)'in yaşantısından alınan örneklerin öğrenciler tarafından derinlemesine incelendiğini ve değerlerden beslenerek oluşan karakter özelliklerinin farkına varıldığını gösterir.

Öte yandan çalışma esnasında; birebir İslam'a ait şart ve sembollerle ilgili kavrama yönelik öğretim yapılmamakla beraber, sonuçta Hz. Muhammed (sav) ile ilişkisi kurulan İslam'a ait şart ve semboller temasında kavram zenginliğinin oluştuğu gözlenmiş̧ir. Kavramlar arası ilişkilerin doğru kurulmasıyla, öğrenmenin temelinin sağlam olacağı bilinmektedir (Aktepe, Cepheci, Irmak ve Palaz; 2017). Öğrencilerin inceledikleri örnek olaylar neticesinde, değerlerin ve karakter özelliklerinin farkına vardıkları kadar, İslam'a ait şart ve sembollere yönelik öğrenmeyi de doğru bir şekilde gerçekleştirdikleri tespit edilmiştir.

Şüphesiz İslam kültürünün değer noktasında en önemli şahsiyetlerinden olan Hz. Muhammed'dir (sav). Araştırma sonucunda toplumsal sorunların farkına varma ve çözme bağlamında; 8. sınıf öğrencilerinin, etkinlik öncesi ve sonras1 çözüm önerilerinin genelde Hz. Muhammed (sav) ile kendilerini özdeşleştirme yönünde değiştiği görülmektedir. Yani öğrencilerin genelinin, yaşanılan sorunlar karşında sergiledikleri barışçıl olmayan çözümlerini, Hz. Muhammed (sav)'in şahsiyeti bağlamında değerlendirildiğinde, barışçıl çözümlere dönüştürdüğü görülmüştür. Ayrıca çoğu öğrencinin etkinlikler öncesinde barışçıl olmayan çözüm önerilerini kendi şahsiyetleri bağlamında da, Hz. Muhammed'i 
(sav) örnek alarak yapıcı çözüm önerilerine dönüştürdükleri de tespit edilmiştir. Bu durum öğrencilerin Hz. Muhammed (sav) ile özdeşim kurduklarını göstermektedir. Ergenlik dönemindeki birey, özdeşleşme objesi olarak kabul ettiği modelde ideal bir üstünlük arar. Bu çerçevede aradığını bazen bir devlet yöneticisinde, bilim adamında bazen de dini şahsiyette bulur (Çamdibi; 1989). $\mathrm{Bu}$ da çalışmanın amacında vurgulanan ergenlik çağına giren gençlere, özdeşleşebilecekleri önemli şahsiyetlerin anlatılmasıyla, onların yaşamında sergilemiş oldukları karakter özelliklerini ve değerlerini, hayatlarında karşılaştıkları sorunlara değerler penceresinden bakarak aktarabilmelerinin mümkün olduğu göstermektedir. Ergenlerin özdeşleşme ihtiyaçları göz önüne alındığında, tarihi şahsiyetlerin değerler açısından doğru bir biçimde anlatılması sonucunda; bireylere sahip olunması istenilen değerler ve karakter özelliklerinin kazandırabileceği anlaşılmaktadır.

Çocuklar okula başlamalarıyla tek sosyalleştikleri kurum olan aile çevresinin dışına çıkmış olurlar. Farklı olaylarla, farklı bir alanda, farklı karakterde insanlarla bir arada bulunurlar. Okulların amacı bu farklılıklar içinde çocukların doğru değer yargılarıyla vatanına, milletine, içinde bulunduğu topluma ve ailesine yararlı birer birey olarak gelişimlerini tamamlamalarına yardımcı olmaktır. Özgür bir ortamda verilen değer eğitimi, kimlik oluşturma eğitimine dönüşebilir (Çağlar; 2005). Yine toplumsal sorunları çözme bağlamında, Hz. Muhammed (sav)'in çözüm önerileri değerlendirildiğinde, Hz. Muhammed (sav)'in kendisinden daha sert tepki vererek çözüm sunacağını dile getiren öğrencilerin, Hz. Muhammed (sav) hakkında var olan bilgilerinin yanlış olduğu görülmektedir. Aileden ya da sosyal çevreden öğrenilmiş bu yanlış bilgi ve algılar ileriye ket vurmaktadır. Bu durumda önce öğrenilen bilgi, sonradan öğrenilen bilgiyi engellemektedir. Yanlış öğrenilmiş bir bilginin düzeltilmesi oldukça zordur (Senemoğlu, 2012). Öğrencilerin yanlış olan bilgilerinin düzeltilebilmesi için öncelikle bu yanlış bilgiyi edindikleri ortamlar da Hz. Muhammed (sav)'in hayatının ve hadislerinin daha doğru öğretilmesi gerekir. İnformal eğitimler yerine formal eğitimlerle aile ve sosyal çevreninde sürece dahil edilmesi, bu tür çalışmanın amacına ulaşabilmesi için gereklidir. Ayrıca bu durum, Din Kültürü ve Ahlak Bilgisi dersi kapsamında yapılan etkinliklerin artırılması gerektiğini de göstermektedir.

Çalışmada değerler açısından farkındalık oluşturmak amaçlanırken, aynı zamanda bireysel ve grup olarak belli becerileri de pekiştirilmiş ve amaca ulaşılmıştır. $\mathrm{Bu}$ amaçlar doğrultusunda, müfredat da var olan kazanımlardan hareketle geliştirilen etkinlikler öğrencilerin; "gruplar arası işbirliği, bir işi devam ettirebilme, empati, eleştirel düşünme, akı1 yürütme, bilimsellik, Kur'an-1 Kerim mealini okuma, araştırma, istişare, zaman yönetimi, etkili iletişim ve sunuş 
becerilerini” göstermişlerdir. Değer eğitimi verilirken dikkat edilmesi gereken temel noktalardan biri de gençlerin değerleri ortaya koyarken, yaşamlarında sergiledikleri iletişim becerileridir ve bu ise günlerinin çoğunu okulda geçiren gençlerin sadece akademik olarak eğitilmesiyle kazanacakları bir şey değildir. Bireyin doğru iletişim becerilerini ve değerleri müfredatta ki kazanımlar üzerinden, yeri geldikçe belirginleştirerek öğrenebileceği çalışma sonucunda görülmüştür. Bireyin öğrendiklerini hayatına aktarabilmesi için sürecin içerisinde aktif bulunması gerekmektedir. Lickona (1991), bireylerin değerleri içselleştirip, değerler sistemini kurabilmeleri için, öğretmenlerin değer eğitiminde izlemesi gereken yolları tanımlarken; sınıfta demokratik bir ortam oluşturmak, öğretmenin ahlaki rehberliği, sınıfı bir ahlak topluluğu haline getirmek, ahlaki disiplin oluşturmak, çatışma çözme yöntemlerini öğretmek, değerleri ders, konu ve işlenişleri ile ilişkilendirmek, eğitimde işbirlikçi öğrenmeyi kullanmak, öğrencilerde elinden gelenin en iyisini yapma alışkanlığ geliştirmek olarak ifade etmiştir (Akt. Kaymakcan ve Meydan, 2014).

Daha öncede belirtildiği gibi bu çalışma Din Kültürü ve Ahlak bilgisi dersi kazanımları bağlamında yapılmıştır. Ancak diğer derslerde de değer eğitiminde örnek olabilecek şahsiyetlerin üzerinde durularak, çocuklara kendileriyle özdeşleştirebilecekleri kişiliklerin tanıtımının etkinliklerle yapılması gerektiği ve bu bağlamda yapılan bu çalışmanın örnek alınabileceği söylenebilir.

\section{Kaynakça}

Aktepe,V., Cepheci, E., Irmak, S., Palaz, Ş. (2017). Hayat bilgisi dersinde kavram öğretimi ve kavram öğretiminde kullanılabilecek teknikler üzerine kuramsal bir çalışma. Uluslararası Sosyal Bilimler Eğitimi Dergisi, 3, 33-50.

Aksoy, N. (2003). Eylem araştırması: eğitimsel uygulamaları iyileştirme ve değiştirmede kullanılacak bir yöntem. Kuram ve Uygulamada Eğitim Yönetimi, 36, 474-489.

Arslan, A. (2017). Hz. Peygamberin (sav) örnekliğinde "güven ve sadakat" a dayalı toplumsal ahlak. Bülent Ecevit Üniversitesi Ilahiyat Fakültesi Dergisi, 4, 1-17.

Çağlar, A. (2005). Okul öncesi dönemde değerler eğitimi. M. Sevinç, (Ed.), Erken çocuklukta gelişim ve eğitimde yeni yaklaşımlar 2, İstanbul: Morpa Kültür Yayınları

Çakan, İ.L., Solmaz, M. (2014). Kuran-ı Kerim'e göre peygamberler ve tevhid mücadelesi. İstanbul: Ensar Yayınc1lı 
Çamdibi, M. (1989). Din eğitimine giriş. İstanbul: MÜİF Yayıncılık

Diyanet İşleri Başkanlığı. (2011). Kuran-ı Kerim meali (12. Bask1). Ankara: Diyanet İşleri Başkanlığı Yayınları

Erdoğan, F., Uysal, H.T., Saki, E., ALTIN, A. (2015). Televizyon eğilimi, özdeşleşme ve medya okuryazarlığı kavramlarının ilişkilendirilmesi: ergenlik dönemindeki çocuklara yönelik bir araştırma. Uluslararası Sosyal Araştırmalar Dergisi, 8, 846-860.

Eskiler, E., Altunışık, R. (2017). Rol model alma davranışının pozitif sözlü iletişim ve satın alma niyeti üzerine etkisinde marka bağl1lığının aracılık rolü. Uluslararası Yönetim İktisat ve İsletme Dergisi, ICMEB, 17, 687696

Güler A., Halıcıoğlu M.B., Taşğın S. (2015). Sosyal bilimlerde nitel araştırma (2. Bask1). Ankara: Seçkin Yayıncılık.

Hökelekli, H. (2009). Çocuk, genç, aile psikolojisi ve din. İstanbul: Dem Yayınları.

Hökelekli, H. (2013). Ailede, okulda, toplumda değerler psikolojisi ve eğitimi. İstanbul: Timaş Yayınları

İbn Hişam. (1971). Hz. Muhammed 'in hayatı. (Çev. İzzet Hasan ve Neşet Çağatay). Ankara: Ankara Üniversitesi İlahiyat Fakültesi Yayınları

Kaymakcan, R., Meydan, H. (2014). Ahlak ve değerler eğitimi. İstanbul: Dem Yayınları.

Kılavuz, M.A. (2002). Ergenlerde özdeşleşme ve din eğitimi. H. Hökelekli (Ed.), Gençlik, din ve değerler psikolojisi (s. 209-254) içinde. Ankara: Ankara Okulu

Köknel, Ö. (1979). Cumhuriyet gençliği ve sorunları. İstanbul: Cem Yayınları

Köylü, M. (2013). Küresel ahlak eğitimi. İstanbul: Dem Yayınları.

Milli Eğitim Bakanlığı. (2017). 8. Sinıf din kültürü ve ahlak bilgisi ders kitabı. Ankara: Gizem Yayıncılık.

Milli Eğitim Bakanlığı. (2010). İlköğretim din kültürü ve ahlak bilgisi dersi (4, 5, 6, 7 ve 8. Sınıflar) öğretim programı ve kılavuzu. Ankara

Müslim, B. H. (1993). Sahih-u müslim. İstanbul: Çağrı Yayınları

Sarıçam, İ. (2006). Değerlerin hayata geçirilmesinde hz. peygamber: Güven örneği. Hz. peygamberin tebliğ metodu ışığında islam'ın güncel sunumu 2003 yılı kutlu doğum sempozyumu tebliğ ve müzakereleri. Ankara: Türkiye Diyanet Vakfı Yayınları 
Sarıçam, İ. (2011). Hz. Muhammed ve evrensel mesajı. Ankara: Diyanet İşleri Başkanlığ 1 Yayınları

Senemoğlu, N. (2012). Gelişim, öğrenme ve öğretim kuramdan uygulamaya (22. Bask1). Ankara: Pegem Akademi.

Tarhan, N. (2016). Değerler psikolojisi ve insan (9. Baskı). İstanbul: Timaş Yayınlar1.

URL 1- http://www.hurriyet.com.tr/gundem/mavi-balinada-olum-zinciri-40taelini-kes-50de-intihar-et-emri-40749744 Erişim: 02 Ocak 2017

URL 2-http://www.milliyet.com.tr/izmir-de-okul-mudurunun-oldurulmesi-van-yerelhaber-2473920 Erişim: 02 Ocak 2017

URL 3- http://www.hurriyet.com.tr/vicdansiz-surucu-otizmli-cocuga-carpip-kacti-40578421 Erişim: 02 Ocak 2017

Yaman, E. (2014). Değerler eğitimi (3. Baskı). Ankara: Akçağ Yayınları.

Yavuzer, H. (1982). Çocuk ve suç. İstanbul: Altın Kitaplar.

Yıldırım, A.; Şimşek, H. (2011). Sosyal bilimlerde nitel araştırma yöntemleri (8.Baskı). Ankara: Seçkin Yayınları. 


\title{
Identification in Values Education: The Case of the Prophet Muhammad (pbuh)
}

\author{
Sevgi COŞKUN KESKIN, Corresponding Author. Assoc. Prof. \\ Sakarya University, Faculty of Education, Turkish and Social Sciences Education Department. \\ E-mail: scoskun@sakarya.edu.tr \\ ORCID: 0000-0001-2345-6789
}

İklima Betül ERTÜRK, M.D. Student.

Sakarya University, Institute of Educational Sciences, Values Education.

E-mail: iklimabetulerturk@gmail.com

ORCID: 0000-0001-7631-9016

Zehra Betül KOCAMAZ, M.D. Student.

Sakarya University, Institute of Educational Sciences, Values Education.

E-mail: zbkocamaz44@gmail.com

ORCID: 0000-0002-2148-8960

\section{Introduction}

The 14-15 age groups, which are known as early youth, is one of the important periods during which identity development. A positive personality development is very important in this period, and the identity formed by the individual determines his/her roles in future life. The environment, family, living standards, and the psychological state of the individual are effective in the formation of identity. In the adolescence period, individuals tend to identify themselves with the people or ideas that are considered popular or famous on mass media, so they go on in search for identify by differentiating themselves from others or identifying themselves with role models. (Köknel, 1979; Yavuzer, 1982). The indi- 
viduals taken as models by children in the identification process may put them into trouble. (See for exemplary news. URL-1, URL-2, URL-3). Value-centered education is highly important in solving these problems. In this case, the best model is, undoubtedly, the Prophet Muhammad (pbuh) who perfectly followed all teachings of Islam.

The Prophet Muhammad is one of the personalities whom individuals will take as role models in the most beautiful way with respect to values such as trust, patience, diligence, responsibility, courage, justice, compassion, tolerance, forgiveness, love, and respect (Çakan and Solmaz, 2014; İbn Hişam, 1971; Müslim 1993). Therefore, the aim of the study was to raise awareness and consciousness of the young so that they could consider the situations they encounter in their lives through the values and "Exemplary Behaviors" of the Prophet Muhammad. When the literature was reviewed, studies on identification and role models during adolescence (Eskiler and Altunış1k, 2017; Erdoğan et al., 2015; Hökelekli, 2013; Kılavuz, 2002; Sarıçam, 2006) were available in terms of theoretical framework, whereas application-oriented studies were not found. In this regard, an attempt to search for answers to the following sub-problems was made based on the problem of "What kinds of solutions are presented for the problems encountered in daily life by identifying with the Prophet Muhammad (pbuh), and which activities can be performed in this regard?"

1- In line with this general problem, the sub-problems of the study are as follows:

2- "What are the $8^{\text {th }}$-grade primary school students' perceptions of the Prophet Muhammad (pbuh)?"

3- "How do the activities performed with the $8^{\text {th }}$-grade primary school students affect students' views on the Prophet Muhammad (pbuh), and with which characteristics of Him do students identify themselves?"

"How do the $8^{\text {th }}$-grade primary school students take the Prophet Muhammad (pbuh) as a model within the context of solving social problems?"

\section{Method}

\section{Research Design}

In this study, the action research design, as one of the qualitative research methods, was used to carry out in-depth examination and analysis in accordance with 
the aim of the study. The researcher-teacher needed to take an active role in the application of the activities, manage the study, look for solutions to existing problems, and make observations (Aksoy, 2003; Güler, Halıcıoğlu and Taşğın, 2015; Yıldırım and Şimşek, 2011). Therefore, the action research method was used in the study.

The study was carried out with the participation of 23 students consisting of 10 female and 13 male students in the 13-14 age group who were promoted to the $8^{\text {th }}$-grade at the secondary school level in a school with a middle level of socioeconomic status in Hendek district of Sakarya province, 2017-2018 academic year.

\section{Data Collection Process and Tools}

8 different activities were developed based on the aim of the study. These activities are as follows: word association, problem analysis with the demonstration method, problem tree activity, case study, poster activity, empathy activity, verse interpretation, and concept map.

\section{Data Analysis}

In the study, the data were analyzed by content analysis. Within the scope of content analysis, data analysis was performed in five stages consisting of data processing, data coding, theme creation, comparison of preliminary information and final information, comparison of student's own solutions with the solutions of the Prophet Muhammad (pbuh), and ensuring validity and reliability.

\section{Results}

\section{Results on Eighth-Grade Students' Perceptions of the Prophet Mu- hammad and How Activities Affected These Perceptions}

The results related to the comparison of students' knowledge of the Prophet Muhammad before and after the activities and also the interpretation of the Prophet Muhammad's characteristic as a human, are presented below.

\section{Comparison of students' knowledge of the Prophet Muhammad before and after the activities}

The Prophet Muhammad's values theme. 11 values of the Prophet Muhammad (respect, love, honest-right, patient, fair, helpful, trustworthy, compassion- 
ate, determined, forgiving, generous, faithfulness) were emphasized by the students before the activity. However, 14 values that were considered to be owned by the Prophet Muhammad (trustworthy, fair/righteous, tolerant, patient, courageous, diligent, compassionate, forgiving, respectful, honesty/rightness, love, helpful, determined, generous, being scientific) were mentioned with increasing frequency after the activities performed. This frequency is almost four times higher compared to the preliminary application $(37 / 171=4.62)$.

The Prophet Muhammad's character traits theme. 9 character traits of the Prophet Muhammad (good person, eloquent, best fellow/friend, cleanliness, morally justified, serious, not being ill-wisher, good-humored, exhibiting good behavior) were emphasized by the students before the activity. As a result of the activities performed, 22 character traits that were considered to be owned by the Prophet Muhammad (pbuh) (he attached importance to knowledge, loved animals and nature, worked by consulting, made use of the time well, etc.) were mentioned.

Pillars and symbols of Islam associated with the Prophet Muhammad theme. In the preliminary application, it was observed that the students established associations with 15 pillars and symbols of Islam that came to their mind when the Prophet Muhammad (pbuh) was mentioned. After the activities, a total of 25 pillars and symbols of Islam were emphasized with increasing frequency. When the applications were compared, the frequency of emphasizing the expressions was almost more than twice $(38 / 88=2.31)$ in the last application.

The theme of Prophet Muhammad's physical characteristics. It was observed that they mentioned the concepts related to the physical characteristics of the Prophet Muhammad (pbuh) in both applications. In the preliminary application, 2 physical characteristics of the Prophet Muhammad (pbuh) (his beautiful face, the beauty of his forehead) were mentioned, however, 3 physical characteristics of him (nice, good-humored, intelligent) were mentioned after the activities had been performed.

The theme of Prophet Muhammad's relationship with Allah. In the first application, students did not mention the relationship of the Prophet Muhammad (pbuh) with Allah. Although the frequency of emphasizing was not very high after the activities performed, they used expressions about the relationship of the Prophet Muhammad (pbuh) with Allah.

The theme of concepts associated with the Prophet Muhammad. It was observed that students associated the Prophet Muhammad (pbuh) with the con- 
cepts of "orphan, fear, world, poverty in old times" before the activity. After the activities, they mentioned the concepts of "jahiliyyah, literate, he was populist, libertarian."

\section{The Perception of the Prophet Muhammad's (pbuh) Being a Human}

After the activities applied, students were asked to interpret the verse "Say, $O$ [Muhammad], "I am only a man (human) like you" (Al Fussilat/6). It was observed that almost all students emphasized that the Prophet Muhammad (pbuh) exhibited exemplary behaviors both as a human being and as a prophet. Furthermore, it was found that most of the students thought that as humans we could also exhibit the behaviors that He exhibited.

\section{The Prophet Muhammad (pbuh) as a role model within the context of solving social problems}

The vast majority of the students indicated that the Prophet Muhammad (pbuh) would solve the problem expressed in a reasonable way than them. Before the activity, the students' own solutions were generally based on punishment method. After the activities, it was observed that non-peaceful solutions of the students turned into peaceful (conciliatory) solutions when they were evaluated within the context of the personality of the Prophet Muhammad (pbuh). When the students were asked again for solutions after the activity, it was determined that the students proposed solutions in parallel with the solutions of the Prophet Muhammad (pbuh).

\section{Discussion, Conclusion and Recommendations}

In the study, some activities related to the Prophet Muhammad as a role model were performed, and the results shows that the students' perceptions of the Prophet were enriched and they took up to Him as a role model. It was found that the $8^{\text {th }}$-grade students mentioned many values and character traits of our prophet such as "being trustworthy, fair, tolerant, patient, courageous, diligent, compassionate, respectful, peace-loving (reconciler), mindful of knowledge, working by consulting, giving value to people" after the application of the activities, in addition to their associations such as "Allah's servant, who teaches Islam, the Quran, prophet" in the preliminary application.

In the Prophet Muhammad's (pbuh) values theme, "being a trustworthy per- 
son" was the most frequently mentioned $(2 / 22)$ value. This may be due to the fact that the value of being trustworthy actually serves as the cornerstone of all values. As it was stated by Arslan (2017), a world in which social peace is achieved occurs along with the fact that people are able to lead a life on the basis of trust because trust leads to the formation and application of values. Sarıçam (2006) states that "universal values are the norms that found to ensure people's trust in each other and to create an environment of trust" this indicates the importance of trust. The reason for the high emphasis on trustworthiness (Al-Amin) trait of the Prophet Muhammad (pbuh) by students stems from their belief that the prophet is a person who reflect many values such as; compassion, justice, respect, patience, and courage, in his life, in other words, he is regarded as a person who lives what he says.

The values owned by an individual are of vital importance since they will determine his/her perspective on events and personality in the future. Therefore, he/she needs to gain and internalize the values (Yaman, 2014). In the study, the value that the students mostly emphasized after the trustworthiness value was "Justice." The reason for the high frequency of emphasizing the value of justice (3/21) may be due to the fact that they observed that the Prophet Muhammad (pbuh) selected and exhibited the best behaviors suitable for every specific conditions he had. One of the wrong interpretation of justice is to perceive it as a form of punishment. According to Tarhan (2016), justice is the philosophical attitude that human has adopted towards a situation. Justice is not only to punish the wrong doings but also to increase the goodness. The value of tolerance, which was never emphasized in the first study, was also mentioned with a high frequency $(0 / 22)$ after the activities. In this part of the study, it was found that the frequency of emphasizing the values of being patient (4/19), courageous $(0 / 18)$, diligent (0/17), compassionate (2/16), forgiving (1/13) of the Prophet Muhammad (pbuh) also increased. This shows us that students became aware of the values emphasized through the exemplary behaviors of the Prophet Muhammad (pbuh).

A society that thinks about its future should raise individuals of good moral character. Moral character is that the individual exhibits what is good in his/ her behaviors without feeling any pressure or constraint of his/her own society in internalizing the value judgments (Hökelekli, 2009). While the concepts of "eloquent, serious" that students stated before in the Prophet Muhammad's (pbuh) character traits theme can be characterized as behaviors including appli- 
cation-oriented value, the concepts that were not application-oriented and generally expressed, such as "good person, best fellow/friend, morally justified, not being ill-wisher, good-humoured, cleanliness, exhibiting good behavior", were emphasized with high frequency. After the activities, students' previous statements turned into statements such as "he attached importance to knowledge, he loved animals and nature, he worked by consulting, he made use of the time well, he gave value to people, angel/good person, he never broke somebody's heart, he never used bad words, he attached importance to his religion, he knew where and how he would behave, he had exemplary behaviors, good friend, normal human, conscientious, he loved and protected us, he was not prejudiced, he considered everything positively, serious, problem solver, he was morally justified besides goodness, he had good manners." This result shows that students believe that values are displayed through behaviors. So, for them what the concepts of a good or a moral person encompassed is identified based on the traits of the Prophet Muhammad (pbuh). The enrichment in students' statements indicates that they examined the exemplary situations taken from the life of the Prophet Muhammad (pbuh) in depth and they were aware of the fact that character traits are formed through values.

On the other hand, although no direct education was provided for the concept related to the pillars and symbols of Islam during the study, ultimately, it was observed that richness of the concept was formed in the pillars and symbols of Islam associated with the Prophet Muhammad (pbuh) theme. It is a known fact that the basis of learning will be sound by establishing correct relations between the concepts (Aktepe, Cepheci, Irmak and Palaz, 2017). As a result of the case studies that examined the students, it was found that they became aware of values and character traits and also properly learned the pillars and symbols of Islam.

With the effects of globalization, the values of the West today no matter how much they are prevalent, they are not sufficient for the welfare and peace of people and society, they cannot find solutions to global problems (Köylü, 2013). Therefore, in the study, the person who served as a model for the solution of social problems was the Prophet Muhammad (pbuh), who is one of the most important personalities with respect to the values taught in the Islamic culture. So in this study, it was observed that the $8^{\text {th }}$-grade students' solutions before and after the activities generally changed in the direction of identifying themselves with the Prophet Muhammad (pbuh), within the context of recogniz- 
ing and solving social problems. In other words, it was observed that students' non-peaceful solutions to the problems transformed into peaceful solutions when they were evaluated within the context of the personality of the Prophet Muhammad (pbuh). Furthermore, it was also found that most of the students turned their non-peaceful solutions after the activities into constructive solutions by taking the Prophet Muhammad as a role model, within the context of their personalities. This indicates that the students identified themselves with the Prophet Muhammad. The individual in the adolescence period seeks an ideal role model with superior traits that he/she would adopt and identify with. And these superior trait sometimes are found in a ruler, a scientist or in a religious person (Çamdibi, 1989).

This also indicates that it is possible for the adolescent to acquire the character traits and values of important personalities with whom they can identify with, and solve the problems they face in their lives by considering them through values, which was emphasized in the aim of the study. When the identification needs of adolescents are considered, it is understood that individuals can gain the desired values and character traits by introducing a historical figures properly in terms of values.

When children start school, they become out of the family environment, where they can socialize. They coexist with people with different characters, through different events, in a different area. The aim of schools is to help children complete their development as a useful individual to their society, nation, and family and equipped with correct values. Value education given in free environment may turn into identity formation process (Çağlar, 2005). Within the context of solving social problems, when the solutions of the Prophet Muhammad (pbuh) are evaluated, it is observed that the students who state that the Prophet Muhammad (pbuh) would offer solutions by giving stronger and stricter reaction than themselves are the ones who have wrong information about the Prophet Muhammad (pbuh). This wrong information and perceptions likely aquired from the family or social environment are misleading. In this case, previously learned information hinders subsequent learning. It is quite difficult to correct mislearned information (Senemoğlu, 2012). Firstly, the life and hadiths of the Prophet Muhammad (pbuh) should be taught more accurately so that the wrong information would be corrected. The inclusion of the family and social environment in the process through formal education instead of informal education is required for such a study to achieve its aim. While Lickona 
(1991) was defining the paths that teachers should follow in value education for individuals to be able to establish a system of values, they highlighting the need for creating a democratic environment in the classroom, getting moral guidance from teachers, turning classroom into a moral community, creating the moral discipline, teaching conflict resolution methods, associating values with the course subject and the way they are taught, using cooperative learning in education, and developing the habit of doing best they can in students (cited by Kaymakcan and Meydan, 2014). This should be applied within the scope of the Religious Culture and Moral Knowledge course, more activities concerning this issue should be done. 